\title{
Assessing the Impact of China's WTO Accession on Investment
}

\author{
Terrie L. Walmsley, Thomas W. Hertel and Elena Ianchovichina*
}

\begin{abstract}
During the early 1990s, foreign direct investment (FDI) in China boomed, subsequently claiming a large share of all Foreign Direct Investment in developing countries. However, the rate of growth in FDI slowed in the later 1990's, as investors' high expectations failed to fully materialize. With China's accession to the WTO at long last a reality, FDI growth has once again picked up. This paper formally explores the linkage between WTO accession and investment in China over the next two decades. The effects of a number of features of China's accession are examined, including: the removal of tariffs and quotas, the potential for improved productivity in the automobile sector due to production rationalization, and finally, the liberalization of rules governing direct trade and foreign investment in the service sectors.

We find that investment and capital stocks increase substantially as a result of China's accession. Moreover, accession doubles the extent of foreign ownership of Chinese assets relative to the no-accession baseline by 2020. Central to this increase in foreign ownership is the expected catch-up in the productivity of the services sectors driven by the opening up of these sectors to foreign investment. The resulting impact on GDP is also large -- 22.5\% higher in 2020 as a result of WTO accession. The static welfare gains $(16 \%$ by 2020) are dampened due to the fact that a substantial share of the additional investment comes from overseas. These estimates are far larger than those predicted by earlier studies, which ignored the reforms affecting the services sectors of China, and which also abstracted from capital accumulation and international capital mobility. Given its critical importance to our analysis, future research should be directed towards narrowing the uncertainty associated with the impact of accession on productivity in the services sectors.
\end{abstract}

\footnotetext{
${ }^{*}$ Walmsley is an Assistant Professor at the Center for Global Trade Analysis, Purdue University, 403 West State Street, West Lafayette, IN 47906, USA, Email: twalmsle @ purdue.edu. Hertel is a professor at the Center for Global Trade Analysis, Purdue University, USA and Ianchovichina is an economist at the World Bank, 1818 H Street, N.W., Washington D.C 20433, USA.

We would like to thank the reviewers of this paper for their useful comments and suggestions. Also we thank the participants of the Fourth Annual Conference on Global Economic Analysis, Purdue University, USA, June and the ESRC Development Economics Study Group Annual Conference, April 2002 for their comments.
} 


\section{Introduction}

Over the last two decades, China has undertaken significant reforms to restructure and open up its economy to foreign trade. These reforms have helped to spur a period of rapid growth, with growth in real per capita GDP averaging 6.04 percent over the period 1978-95 (Maddison, 1998). However, reforms to the legislative framework governing foreign investment in China have proceeded more slowly. Entry in certain sectors, as well as the share of foreign ownership, is significantly limited and joint ventures typically remain the best option for foreign investors. In an effort to boost foreign investment, the Chinese government began offering a number of special incentives in the early 1990's, including duty drawbacks on imported intermediate inputs and capital goods used for the production of exports, exemptions and reductions in the rate of income taxes paid on profits, ${ }^{1}$ and preferential tax rates for foreign enterprises which re-invest their profits (China Council, 2000). These incentives paid off, with foreign investment increasing sharply in 1992-93 (Figure 1). Indeed, by 1994 China accounted for approximately 20 percent of all Foreign Direct Investment (FDI) in developing countries (Garbaccio, 1995).

However, by 1996 the rate of growth in FDI had begun to slow (Figure 1). A survey of the Chinese economy by The Economist (2000) explored some of the reasons behind the FDI slowdown in China. In many cases investors' high hopes for this market were slow to materialize, with the absence of a rules-based economy making it difficult for outsiders to operate effectively in China. Informal relationships and corruption still hinder many business transactions by foreigners. In addition, inefficient state enterprises still dominate many key sectors of the economy. China's push for accession to the World Trade Organization (WTO) was partly an attempt to remedy some of these more fundamental problems, thereby promoting foreign investment. Indeed, the recent upturn in FDI provides some evidence that investors have responded positively to China's accession. It is this linkage between WTO accession and foreign investment that provides the focal point for our paper.

\footnotetext{
${ }^{1}$ Incentives are numerous and depend on the sector and/or the region within China where the investment is undertaken as well as the purpose of the production activity (e.g., export sales). The duration of incentives also varies, and may be for a period of up to five years (China Council, 2000).
} 
China's bid to rejoin the GATT began in 1986, and culminated in the recent Doha meetings of the WTO, when membership was finally approved by that body. The final accession agreement reflects the importance, to the US and European negotiators, of increasing access for foreign investors - particularly in the services sectors. In the words of Aaditya Mattoo of the World Bank: "China's GATS commitments represent the most radical services reform program negotiated in the WTO. China has promised to eliminate over the next few years most restrictions on foreign entry and ownership, as well as most forms of discrimination against foreign firms" (Mattoo, 2001). Clearly the stage is set for increases in foreign investment.

Domestic investment is also expected to rise as a result of WTO accession. In the nineties FDI inflows surged because domestic firms were uncompetitive, domestic savings were inefficiently allocated and laws put domestic companies at a disadvantage relative to foreign companies (Huang, 2002). ${ }^{2}$ Tax advantages for export processing has benefited mainly foreignowned companies, while domestic content requirements restricted the use of imported intermediate inputs by companies selling locally and were a particular problem for the domestic automobile industry. In preparation for WTO accession China reformed its export processing system and extended tax benefits to all companies producing exports, not only the foreign-owned ones. Commitments as part of WTO accession have led to the removal of the local content requirement, and reforms will ensure fair treatment for both domestic and foreign companies (no discrimination) and more efficient use of domestic savings. Therefore, it is expected that China's WTO accession will have a positive impact on domestic investment.

The accession agreement also provides for the reduction of tariffs, the implementation of tariff bindings, and elimination of quantitative restrictions. These have been the focus of the vast majority of previous papers on China's WTO accession.

In this paper we explore the implications of China's accession to the WTO for investment in China using a revised version of the dynamic GTAP model (GTAP-Dyn) (Ianchovichina and McDougall, 2001), which explicitly accounts for duty drawbacks by modeling the export processing sectors separately. This analysis goes beyond the impact of the associated tariff cuts. It examines the impact of the liberalization of rules governing direct trade in services, the

\footnotetext{
${ }^{2}$ The result was an increase in FDI even in industries in which Chinese firms have been strong in the past such as textiles, herbs, and others.
} 
elimination of quantitative restrictions on textiles and apparel exports to North America and the European Union, and the impact of prospective productivity gains in the automobiles and services sectors.

Our basic macro-economic results confirm the findings of the earlier studies (Ianchovichina and Martin, 2001, 2003; Wang, 2001) with China expected to gain most from accession. The new insight from our paper relates to the implications for investment and ownership of productive assets. We find that accession significantly boosts investment, doubling the extent of foreign ownership of Chinese assets relative to the no-accession baseline. Central to this increase in foreign ownership is the expected boost in productivity of the services sectors owing to the liberalization of rules governing foreign investment in these sectors.

The next section of this paper reviews the literature examining China's accession to the WTO. Section 3 introduces the analytical framework employed to understand the economy-wide implications of China's WTO accession, and specifically, the link between accession and investment. Section 4 discusses the details underlying the design of the accession scenario. Section 5 examines the results of this scenario, comparing them to the baseline. Finally section 6 summarizes the findings and offers concluding remarks.

\section{Literature review}

China's accession to the WTO has generated a large amount of interest and extensive research has already been undertaken on this topic. Most of this work has focused on the trade implications of accession - largely abstracting from the likely impact on investment. Anderson et al. (2000) used the GTAP model to determine some early estimates of the effects of China's accession. Ianchovichina and Martin $(2001,2003)$ updated these estimates by taking into account duty drawbacks in China. ${ }^{3}$ Wang $(1997 a, 1997 b, 2001,2002)$ has also undertaken a number of studies examining the effects of China's WTO accession using the GTAP Data Base. In general, the results show that world trade increases substantially as a result of China's accession. The main winner from China's accession is China itself. North America and many of the other developed nations also gain as a result of increased exports, particularly of agricultural products (Wang, 1997a). The removal of quotas for China's apparel and textile exports under the ATC

\footnotetext{
${ }^{3}$ Lejour (2000) also examined the effect of duty drawbacks on China's accession using the GTAP model.
} 
agreement appears to be a significant contributor to the benefits accruing to North America. These results are consistent with the findings by other authors (Hertel et al., 1996; Harrison, Rutherford and Tarr, 1996; Walmsley and Hertel, 2001; Yang, 1996).

Analysis of the impact of China's WTO accession on investment has been much more limited. McKibbin and Tang (2000) - henceforth MT - offered an early assessment of this issue. They used the G-cubed model to examine the effect of three possible developments in China: a) the liberalization of trade; b) the liberalization of financial markets; and c) the possibility that financial liberalization might result in a financial crisis within China. MT found that financial liberalization could result in significant gains, particularly for China itself. They did caution, however, that many of the problems affecting the Asian economies at the time of the Asian crisis, such as a fragile banking system, were also features of the Chinese economy, and therefore argued that financial liberalization would be much riskier than liberalization of trade. However, there are a number of limitations to the MT analysis. Firstly, they used a very old data base (1991), which reflects a very different Chinese economy than that which is poised to join the WTO. A second limitation is that their analysis was not based on China's actual offer to the WTO. Instead their accession scenario was highly stylized, representing full removal of protection in China from their 1991 base. Finally, MT did not reflect the system of preferences for export-enterprises in China. Of particular importance is the fact that in $200060 \%$ of China's imports entered the country duty-free due to the current system of duty-exemptions for export processing firms; implying that the gains from trade liberalization will be smaller than the estimates obtained without taking into account duty exemptions.

Ianchovichina (2003) found that the failure to account for duty drawbacks could lead to a substantial overstatement of the impact of WTO accession on China's light manufacturing industry. For example, she showed that failure to account for China's duty exemptions in analyzing WTO accession resulted in overstating the increase in China's trade flows by 40 percent and exports of selected sectors by 90 percent. This limitation is even more severe when one considers the fact that the duty exemptions have been extended to investment goods imported by joint ventures and foreign-owned companies.

Walmsley and Hertel (2001) (WH) offer a more recent assessment of China's WTO accession. While their paper focuses on the uncertainty in the timing of abolition of textile and 
apparel restrictions on China's exports, they also report findings related to changes in foreign investment resulting from China's WTO accession. The WH analysis shares several important features with the present paper. However, they, too, fail to account for the duty drawback regime currently in place in China. In addition, WH ignore the problem of revenue replacement. Another significant limitation of the WH paper has to do with the construction of the baseline scenario in which the authors show foreign investment declining after 1997. This does not square with what has been observed since 1999. Moreover, WH focus only on the issue of trade liberalization, while this paper extends the analysis to encompass liberalization of trade and investment in services.

We address many of the shortcomings of the WH paper and focus specifically on the liberalization and productivity gains in the services sector. GTAP-Dyn (Ianchovichina and McDougall, 2001), used in this paper, places international capital mobility at the forefront, thereby providing a useful vehicle for exploring the impact of China's WTO accession on investment and economic growth in China. We also deal directly with the problem of duty drawbacks by modeling the export processing sectors separately. Furthermore, while tariff revenue has receded somewhat from its previously prominent position in the overall revenue picture for China (tariffs comprised only 6\% of total revenue in 1998 versus 14\% in 1990), the fiscal implications of accession remain an important issue. Therefore, we assume that the Chinese government will replace lost tariff revenue with increased consumption taxes. This seems quite reasonable, as it reflects a continuation of the trend over the past decade in which consumption taxes rose from $18 \%$ to $79 \%$ of total revenue.

The accession agreement used in the paper is based on the August 1999 offer agreed between China and the United States and is obtained from Martin et al. (2000). ${ }^{4}$ The agreement involves the gradual reduction of China's tariffs, which this paper assumes will commence in 2002, and will be completed 5 years later, by the beginning of 2007. Taiwan's (China) accession, which immediately followed on the heels of China's accession, is also included in the analysis.

\footnotetext{
${ }^{4}$ In most studies on China's WTO accession, including Ianchovichina and Martin (2001) and Wang (2001), the bilateral agreement between the U.S. and China served as the basis for determining the extent of liberalization due to WTO accession. The agreement cannot be represented as a move to free trade or a simple proportional cut in protection as many studies have tried to do (see Gilbert and Wahl (2001) for a survey). More recently, Ianchovichina and Martin (2003) used the final multilateral commitments, which became publicly available after the Doha meeting. Their results confirm that the U.S.-China bilateral agreement indeed serves as a good basis for assessing the extent of liberalization in China as part of WTO accession.
} 
In addition to reducing tariffs on goods, we examine the liberalization of rules governing direct trade in services Estimates of tariff equivalents in the services sector for both China and Taiwan (China) were obtained from Francois and Spinanger (2002). These are reduced to examine the potential effect of services liberalization on foreign investment in China.

Accession to the WTO is also expected to produce significant benefits to China through additional productivity growth due to consolidation of the automobile industry and the opening up of the service sectors to foreign investment. Francois and Spinanger (2002), estimate that productivity in China's automobile sector will increase by $20 \%$ as a result of accession. This is comparable in magnitude to the estimates of Mai, Horridge and Perkins (2003) who predict a productivity increase of $1.8 \%$ per year over 10 years for strategic manufacturing industries, including autos and parts. Productivity gains are also expected in the services sectors. Mai et al. (2003) estimate an increase in productivity of $2.7 \%$ per year over 10 years in the services sectors as reforms take place under WTO accession. In this paper we adopt the Francois and Spinanger (2002) estimates for automobile production, and we scale down the estimates of Mai et al. (2003) for services. Specifically we assume productivity improvements in services which climb gradually, reaching a peak of $1 \%$ per year in 2007 , thereafter declining to zero. In an appendix, we also examine the case where productivity reaches a peak of $2.7 \%$, the annual growth rate estimated by Mai et al. (2003).

Finally, special attention is given in the baseline to tracking the growth rate of foreign ownership over the period 1995-2002 and reflecting the fact that the removal of restrictions on foreign ownership and trade reform in China in anticipation of WTO accession has already had a significant effect on the share of foreign investment. We assume that the continued removal of restrictions on foreign ownership, as part of China's accession, will continue to attract foreign investment, although at a declining rate over the period 2002-2007.

\section{The Model}

In order to analyze the impact of China's WTO accession on foreign investment, we extend GTAP-Dyn (Ianchovichina and McDougall, 2001) to take into account duty exemptions on imported inputs and capital goods used in the production of China's exports. ${ }^{5}$ GTAP-Dyn is a

\footnotetext{
${ }^{5}$ We incorporate duty drawbacks into the model following the method outlined in Ianchovichina (2003).
} 
recursive dynamic extension of the GTAP model (Hertel, 1997; www.gtap.org), which is a multi-region applied general equilibrium model. The dynamic model preserves all the features of the GTAP model, while enhancing the investment theory to incorporate capital accumulation, and international capital mobility and ownership. We apply the model to version 4 of the GTAP Data Base $^{6}$ (McDougall et al., 1998), aggregated into 11-regions and 13-sectors (Table 1). The GTAP Data Base is supplemented with foreign income data from the IMF Balance of Payments statistics in order to track international capital mobility and foreign wealth.

Given the focus of this paper on investment, we dedicate the remainder of this section to a brief discussion of the investment theory in the model and the determination of foreign ownership.

\subsection{Investment Theory of the Dynamic GTAP Model}

The investment theory in GTAP-Dyn (Ianchovichina and McDougall, 2001) allows us to link economic activity over time while keeping track of endogenous regional capital stocks and financial wealth, international investment and income flows. Investment funds are used for the purchase of physical investment goods, which are then added to the existing stock of physical capital (Equation 5, Box 1).

The theory offers a disequilibrium approach for allocating investment across regions. Investors respond to expected rates of return and act so as to eliminate errors in their expectations gradually over time. In the process of adjustment, investors gradually eliminate any differences in the rates of return across regions that might exist in the short run by reallocating capital from regions with lower rates of return to regions with higher rates of return. This leads to equalization of rates of return across regions only in the long run. ${ }^{7}$

The determination of investment in the model may be illustrated with the help of Figure 2. The expected rate of return schedule depicts the relationship between the expected rate of return $\left(\mathrm{R}_{E}\right)$ and capital stock $(\mathrm{K})$, while the actual rate of return schedule shows the relationship

\footnotetext{
${ }^{6}$ Results are similar when the model is applied to the more recent version 5 of the GTAP Data Base (see Ianchovichina and Walmsley, 2003).

${ }^{7}$ The disequilibrium approach is necessary to reconcile the theory of investment with observed reality. In many cases actual investment, as reported in the national statistics, does not correspond to that predicted by theory. For example, observed rates of return may be very low while observed investment is high. Such discrepancies can be rectified in one of two ways - either the data can be altered so that theory and data are consistent, or alternatively, the theory can be modified to more accurately reflect empirical reality. In GTAP-Dyn the latter method was used.
} 
between the actual rate of return $\left(R_{A}\right)$ and capital stock $(\mathrm{K})$. These curves are downward sloping reflecting the belief that, as capital stocks increase, rates of return will fall, ceteris paribus. The difference between these two schedules is a result of errors in expectations (i.e. the difference between observed data and the postulated theory). In any given year, there is a temporary equilibrium global rate of return, $R_{T}$ that ensures that global savings equal investment.

Investment in a particular year is determined by three mechanisms. The first one, which forms the second part of equation 1 (Box 1), is the desire to eliminate errors in expectations The expected rate of return falls by a portion (determined by $\mu$ ) of the error in expectations $\left(\log \left(R_{A} / R_{E}\right)\right)$ during the period $(\mathrm{dt})$. Over time as the expected and actual rates of return converge, this error will be eliminated. In Figure 2 this involves the movement of the expected rate of return schedule towards the actual rate of return schedule (arrow 1 in Figure 2).

The second one, incorporated into the model via equation (2) (Box 1), is the gradual equalization across regions of rates of return. This requires the movement of the expected rate of return in all regions towards the temporary equilibrium $\left(\mathrm{R}_{\mathrm{T}}\right)$, common to all regions (arrow 2 in Figure 2). Differences between the expected $\left(R_{E}\right)$ and target $\left(R_{T}\right)$ rates of return determine the expected rate of growth in the expected rate of return $\left(\Gamma_{E}\right)$. These differences are gradually eliminated at a rate determined by $\Lambda$.

The third mechanism is the equalization of all three rates of return. In the long run the target and expected rates of return will have converged, leading to an expected rate of growth in the rate of return of zero (equation 2, Box 1). Errors will also have been eliminated $\left(R_{A} / R_{E}\right.$ equals 1) and there will be no tendency for the expected rate of return to change $\left(\hat{R}_{E}=0\right)$. For this to occur the growth rate of capital must equal the normal growth rate of capital (first part of Equation 1, Box 1) and investment and capital must be changing at the same rate (Equation 3 , Box 1$)^{8}$. Otherwise, rates of return may overshoot the target rate of return. Only when all these conditions are satisfied will a permanent long-run convergence of rates of return occur.

\footnotetext{
${ }^{8}$ In addition there should be no tendency for the normal growth rate of capital to change $(\omega=0$, Equation 4 in Box 1). Since the normal growth rate is that rate of growth consistent with no changes in the rate of return, changes in the normal growth rate may arise if the current normal growth rate does appear to lead to changes in the rate of return.
} 


\section{Box 1: Investment theory of GTAP-Dyn.}

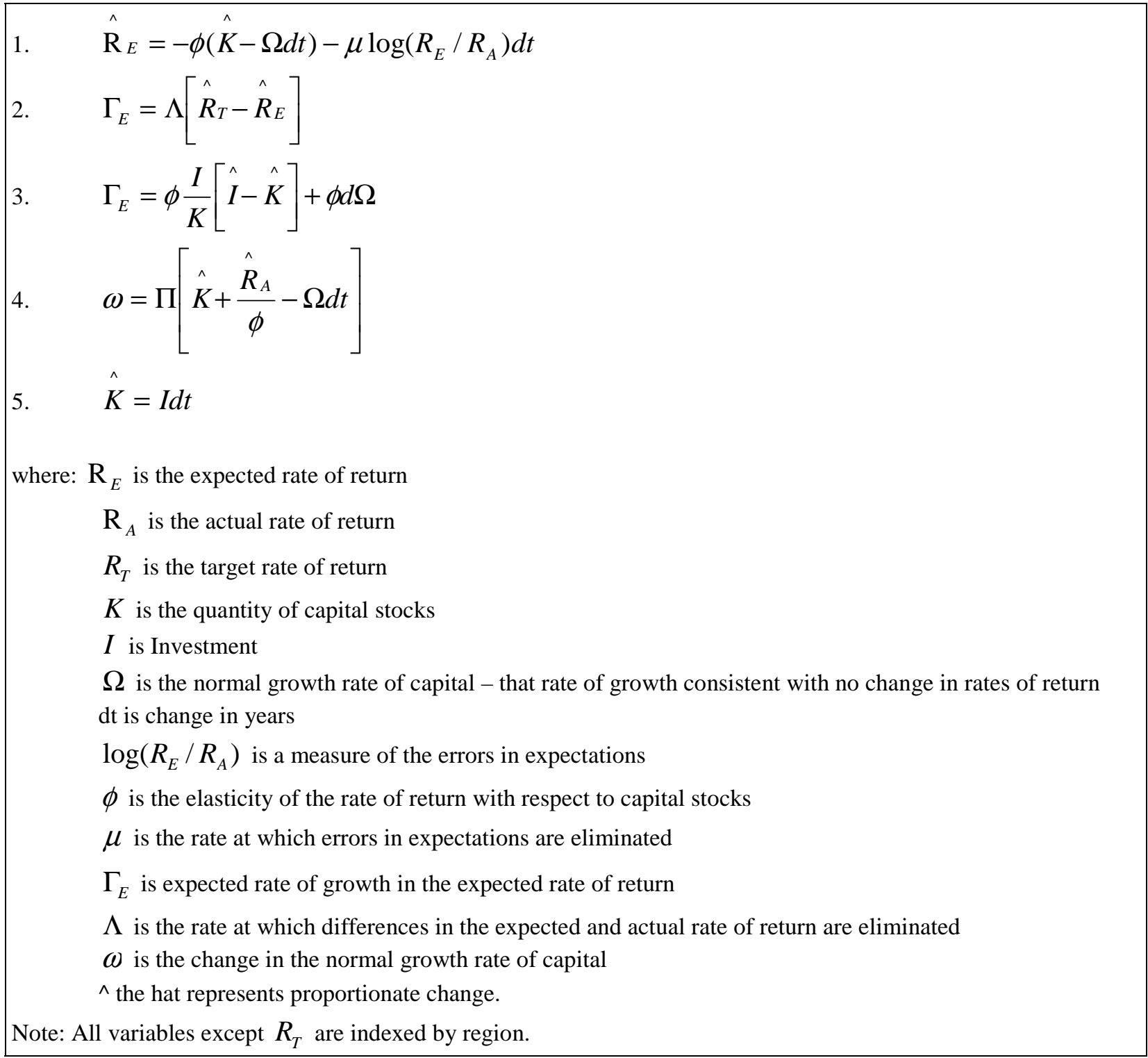

\subsection{Foreign Ownership}

With the incorporation of capital accumulation, it becomes necessary to take account of foreign capital ownership. With regard to foreign investment, the theory respects the empirical regularity that regions tend to invest primarily in assets located in their domestic economy, with a smaller portion of investment coming from abroad. In GTAP-Dyn, financial assets represent claims on earnings from regional physical capital, owned by domestic households, as well as by 
foreign households (via a global trust). ${ }^{9}$ In the absence of policy reforms the share of each regional household's wealth in domestic and foreign firms and the share of each region's capital stocks owned by domestic and foreign residents are held as close as possible to their initial values, subject to adding-up constraints. The proviso "subject to the adding-up constraints", means that these shares are likely to change, however the change is minimized. For example, if national saving rises faster than national investment then the share of investment funded through domestic saving is likely to rise.

Explicit modeling of the ownership of national investment in China allows us to track the accumulation of wealth by foreigners, thereby ascertaining how China's accession to the WTO might affect foreign investment and ownership in China. Moreover, by tracking foreign and domestic ownership, the income accruing from the ownership of these foreign and domestic assets can then be appropriately incorporated into regional income, and hence into the calculation of welfare, both for China and for the rest of the world.

\section{Modeling China's Accession to the WTO}

The effects of China's accession are examined over the period 1995 to 2020. This time frame is divided into a number of unequal intervals to provide the highest resolution over the accession period. These intervals are as follows: 1995-2000, ${ }^{10} 2001,2002,2003,2004,2005$, 2006, 2007, 2008, 2009, 2010, 2010-2015, 2015-2020.

Two simulations are undertaken representing the baseline (without China's accession) and the policy scenario (with China's accession). The baseline scenario provides a picture of what we expect the world economy to look like without China's accession to the $\mathrm{WTO}^{11}$ and is based on Walmsley, Dimaranan and McDougall (2001). The policy simulation examines the effect of China's accession on both domestic and foreign investment. We assume that accession commences in 2002 and that it takes 5 years to implement the agreement; hence accession is

\footnotetext{
${ }^{9}$ The global trust collects all the regional saving allocated to foreign investment, and then allocates it across regions to investment. It is a fictitious agent invented to simplify data requirements for the global model. Without the global trust, a region's saving would need to be allocated bilaterally (nxn data values, where $\mathrm{n}$ equals the number of regions). One of the disadvantages of the global trust method however, is that a small part of the foreign investment undertaken by a region may flow back into the region via the global trust. This will lead to an overestimation of foreign investment and an underestimation of domestic investment.

${ }^{10}$ The period starts from the beginning of 1995 and ends at the beginning of 2000.

${ }^{11}$ The baseline scenario uses the model adjusted to take account of duty drawbacks in China.
} 
expected to be completed by the beginning of 2007, but the effects on foreign ownership and income payments are expected to linger for another decade, as we will see in our results which extend to 2020 .

For comparison purposes and because the reader may find some of elements of the simulation more convincing than others, we examine both the total effect of China's accession, as well as the individual contribution of five components, representing five different elements of China's accession agreement, to the changes in investment and welfare. These components are:

1. the gradual reduction in risk premium expected by foreign investors;

2. the removal of tariffs and quotas as outlined in the agreement;

3. the liberalization of cross-border trade in services;

4. the expected improvements in productivity in the automobile sector resulting from accession; and

5. the liberalization of rules governing foreign commercial presence in the services sector and associated sector-specific productivity impacts.

In light of the fact that readers may find some of these elements more convincing than others, we examine both the total effect of China's accession on foreign investment, as well as the individual contribution of each of these elements of accession, to the changes in foreign investment and welfare. In the remainder of this section, we discuss the policy scenario in detail, including the shocks used to incorporate each of these aspects and the assumptions made. ${ }^{12}$

\section{a) The gradual reduction in risk premium expected by foreign investors}

Data on the value of foreign investment in China obtained from IMF Balance of Payment Statistics (1999) and China's statistical yearbook (2002: Figure 1) suggest that foreign ownership in China has increased significantly more over the pre-accession period than was justified by the changes in expected rates of return resulting from the pre-accession tariff cuts and the assumption of minimizing any changes in the portfolio shares of foreign and domestic

\footnotetext{
${ }^{12}$ Note that the liberalization of services (points 3 and 5 above) are discussed simultaneously under the heading 'd) Services Liberalization', due to their interrelated nature. However, in analyzing the results we chose to separate the effects of services trade liberalization and productivity improvements in the services sector for the reasons outlined above - namely that readers may be less convinced of China's ability to attain the productivity gains assumed in this paper.
} 
investment in GTAP-Dyn. ${ }^{13}$ The increase in the share of foreign ownership in China may have been the result of a number of factors including tax incentives for foreign direct investment, and removal of restrictions on foreign direct investment in some industries (mostly notably light manufacturing and electronics) and a decline in risk premia, which have occurred as China gradually opened up its economy and accession to the WTO became increasingly assured.

Despite creating incentives for FDI in the nineties, as of 2002 China still has a long way to go in terms of removing restrictions to foreign direct investment - joint ventures remain the best way for foreigners to invest in China and certain sectors such as services were closed to foreign investment until recently. We therefore assume that foreign ownership will continue to increase relative to the baseline ${ }^{14}$ as risk premiums continue to fall, although the effect will diminish gradually. Hence by 2007, any affinity by foreign investors to increase foreign ownership in China, caused by China's opening up to foreign investment, will most likely have been eliminated. $^{15}$

\section{b) Tariffs and Quotas}

Constructing an accurate accession scenario is a complex task - even when it comes to tariff cuts. The tariff reductions agreed to by China as part of the accession offer were obtained from Martin et al. (2000) and are based on China's offer as of August, 1999. However, in many cases, these reductions had already been implemented as part of China's preparation for WTO accession. The approach that we take is to compare the offer to China's 1997 applied tariffs. Where the binding is lower, the offer is taken as a change in policy. Table 2 shows China's tariff

\footnotetext{
${ }^{13}$ According to foreign investment data, the growth rate of domestic ownership in 2000 was $10 \%$ less than the model would have predicted given the actual and expected rates of return in the baseline scenario. In 2001 it was $9 \%$ less than the model predicted.

${ }^{14}$ Some might argue that the increased share of foreign ownership should be viewed as part of the baseline scenario, reflecting the fact that it is the result of China's broader attempts to open up its economy and introduce a rules-based system. Alternatively, it might be argued that the two are inseparable, and thus at least part of the decline in risk premiums is related to accession. We find that a good way to think of this is to consider the true "counterfactual": What would happen if China's accession had failed? Would this trend continue or is it more likely that foreign investors would reconsider their positions in China? We believe that the latter would have been more likely. For this reason we have chosen to include a continued rise in foreign ownership as part of China's accession. Of course, we separate this effect for purposes of analysis and permit the reader to apply her/his own judgment in this matter.

${ }^{15}$ This type of approach, which uses historical data to infer future changes, was formalized by Dixon and Rimmer (2002). Baldwin, Francois and Portes (1997) adopt a similar approach in modeling the impacts of EU enlargement on investment in Central and Eastern Europe.
} 
rates before and after accession. In the case of Taiwan (China), the cuts are based on their announced target of 4 percent average tariffs for manufactures. ${ }^{16}$

The reduction in tariffs is assumed to occur in equal installments over the entire period and to refer only to imported intermediate goods for the production of commodities for domestic consumption, as well as, to other imports for final private and government consumption. China's tariffs on imported intermediates used for the production of exports and investment goods remain unchanged and are zero reflecting the presence of duty exemptions. Finally, in order to avoid biasing our accession results by permitting the government to run an increased deficit as a result of accession, we offset these tariff cuts with increases in the current consumption tax in order to maintain unchanging total tax revenue, relative to net national income over the period 2002 2007.

We also assume the quotas on China's textiles and clothing exports to North America and European Union will be removed by the beginning of 2007. Based on experience with implementation of the Agreement on Textiles and Clothing under the Uruguay Round Agreement of the WTO (Spinanger, 1999), we assume that liberalization of the quotas on imports from China and Taiwan (China) will be back-loaded with the bulk of the impact not felt until the final two years. Specifically, we follow the method used in Walmsley and Hertel (2001), except that accession does not commence until 2002.

\section{c) Productivity in the Automobiles Sector}

The automobile sector is currently one of the most heavily protected industries in China, with an average pre-accession tariff rate for vehicles of about $70 \%$. In addition, barriers to internal trade in automobiles have arisen in response to the efforts of individual provinces to foster their own auto industry. Government also sets prices and limits competition in order to favor local producers (Francois and Spinanger, 2002). As a consequence, the opening of this sector to world trade is expected to give rise to substantial restructuring and rationalization of the motor vehicle industry. Francois and Spinanger (2002) point out that the thirteen plants currently producing sedans in China average only 39,000 units per year - roughly a tenth of the minimum

\footnotetext{
${ }^{16}$ No data were available on Taiwan's (China) offer for agriculture at the time of writing, and hence no shocks were applied. More recently data on Taiwan's accession agreement have become available. Results using Taiwan's actual accession agreement can be found in Ianchovichina and Walmsley (2003). The results for China, the focus of this paper, do not change significantly as a result of including Taiwan's actual accession agreement.
} 
efficient scale, by world standards, and that WTO accession could bring as much as a $20 \%$ increase in total factor productivity in the autos sector.

In this paper, we adopt the Francois and Spinanger productivity gain estimate, and just as they do we assume that the increase in productivity of the auto's sector is expected to occur in the assembly of automobiles, rather than in the production of parts. Since our analysis is dynamic, we must also distribute these gains over time. For this purpose, we assume that the gains in productivity occur slowly, peaking in the last year of accession (2006) and then falling back to the baseline rates by 2010 as illustrated in Figure 3.

\section{d) Services Liberalization}

As noted in the introduction, China's commitments in the services sector "represent the most radical services reform program negotiated in the WTO" (Mattoo, 2001, p.1) and, in this sense, are the most significant part of China's WTO accession package. Therefore, omitting the services commitments from the evaluation of WTO accession, ${ }^{17}$ seriously underestimates the gains from trade reform in China.

The WTO groups services commitments into four "modes": (1) the delivery of services across national borders (direct trade in services), (2) the consumption of services abroad (e.g., tourism), (3) commercial presence (i.e. foreign direct investment in the services sector in China), and (4) the movement of natural persons (foreigners providing services in China in person). For purposes of our study, we focus on modes 1 and 3, as they appear to be quantitatively the most important, and have the strongest implications for foreign investment - particularly commitments with respect to mode 3 - commercial presence in the services sector.

Cross-border supply of services: According to Mattoo (2001, p. 7) China has committed to allow the cross-border supply of professional services, to remove quantitative limitations on accountancy firms, to offer taxation services outside of 'economically developed areas', and improve urban planning and legal services. Cross-border supply of education services is also fully open. Commitments on cross border supply in the area of logistics, distribution and transport are mixed. While nothing is offered at the wholesale distribution level, the cross-border supply of retail services through mail-order is allowed - presumably opening the door to retail e-

\footnotetext{
17 The vast majority of studies have abstracted from commitments in services when evaluating the economy-wide impacts of China's WTO accession.
} 
commerce. In the area of transport services, there are provisions relating to cross-border supply of airline services, as well as maritime services to the 130 ports that are open to foreign shipping (Wenping and Findlay, 2001).

Francois and Spinanger (2002) provide estimates of the tariff equivalents of these nontariff barriers before and after China's accession for wholesale and retail trade, transportation, communication, construction, finance, insurance and real estate services, other commercial services and other services (such as public health). We use these tariff equivalents to estimate the reduction in price resulting from the liberalization of services. The tariff equivalents are aggregated using weights obtained from the GTAP Data Base to determine the pre and postaccession tariff equivalents for the three services sectors used in this analysis. (See Table 2 for shocks for China). As with tariffs, we assume that the liberalization of direct trade in services occurs gradually over the accession period (2002-2007). In order to introduce the impact of these cuts in tariff equivalents on direct trade in services, we use the approach developed in Hertel, Walmsley and Itakura (2001, henceforth HWI).

Foreign Commercial Presence in Services: From the point of view of foreign investment, the most important aspect of the services agreement is that pertaining to commercial presence, since this has a direct impact on the constraints facing firms interested in investing in China's services sector. Of special interest are the anticipated changes in telecommunications, transport, logistics, and financial services. In the telecommunications sector, foreign companies can provide value-added and mobile telephone services only in (and between) the three richest metropolitan areas (Shanghai, Guanzhou and Beijing), and this must be done through joint ventures with majority Chinese ownership. With WTO accession, by 2004, fixed line services may also be provided by foreign companies and by the end of the accession period geographical restrictions will be eliminated and equity restrictions will be relaxed (Mattoo, 2001). These reforms promise to make a relatively competitive mobile phone market even more efficient, while the fixed line service is expected to undergo major increases in productivity (Pangestu and Mrongowius, 2001).

China's commitments in the logistics area are particularly striking. By 2006, the distribution services sector will be largely open to foreign investment, with few ownership restrictions and no geographic restrictions (Mattoo, 2001). This is a sector that has hitherto been 
largely in the domain of the state planners, with each sector organizing its own warehousing and storage activities. At the local level, government and enterprise functions were not separated, so the administration of the logistics sector was severely fragmented (Wenping and Findlay, 2001). The infusion of foreign supply chain expertise could have a profound impact on productivity in this sector. Road and rail transport services are also scheduled for full liberalization by 2007, which opens the possibility of much more effective use of multi-modal transport activities (Mattoo, 2001). In short, there is enormous scope for productivity gains in the key transport and logistics activities that lubricate a modern economy.

WTO accession also has substantial implications for the financial services sector. Prior to accession, foreign banks could only operate in a few regions, and only accept deposits from nonresidents and only in foreign currencies. Under accession, this sector will be gradually, fully liberalized. First the geographic restrictions will be eliminated, then the local currency restriction will be dropped in selected regions and by 2006, the banking services will be fully liberalized. Similar liberalization will be undertaken in the insurance services sector. These changes promise to greatly increase competition and productivity in financial services.

Since most of the reforms to rules governing foreign establishment of commercial presence in services are phased in gradually, we implement the asymmetric, triangular pattern of productivity shocks (Figure 3). The maximum deviation from baseline occurs in 2007, when productivity growth is assumed to be $1 \% / y$ ear relative to the baseline rate of growth. ${ }^{18}$ This WTO-induced effect subsequently diminishes and disappears by 2010, leaving total factor productivity in the services sector $4.58 \%$ higher than under the baseline in 2010.

This productivity enhancement appears to be rather modest in light of the major reforms being undertaken by China and the findings of Mai, Horridge and Perkins (2003), which uses historical simulations to estimate potential productivity growth in services in China over the accession period. They predict a productivity growth of $2.7 \%$ per year in services over a 10 year period following accession. We therefore also explore the effect of a higher rate of productivity growth - where productivity growth is assumed to peak at $2.7 \% /$ year relative to the baseline rate

\footnotetext{
${ }^{18}$ Note there is no sector-specific productivity differential in the baseline. Region-specific productivity is calibrated to achieve forecasted GDP growth.
} 
of growth (See Appendix 1). ${ }^{19}$ As we will see below, even these smaller cumulative productivity shocks are sufficient to play a dominant role in the overall accession story.

\section{Impact of China's WTO Accession}

In this section, the results of China's accession are discussed. We begin by providing an overview of the macro-economic effects of accession on capital accumulation and investment before turning to the specific question at hand - namely the impact on domestic and foreign ownership. The section concludes with a summary of the long run welfare consequences of China's accession.

\section{Macroeconomic impact on Capital Accumulation}

A comprehensive picture of the global impact of China's accession is given in Table 3. The results report the cumulative percentage changes relative to the baseline at the beginning of 2020, thus highlighting the long-run effects of China's entry into the WTO. Overall the results concur with the findings of other research - China and Taiwan (China) are the primary beneficiaries from China's accession in terms of both production and welfare (Table 3). In the long run, with the additional accumulation of capital, these benefits are even more pronounced. Here, we trace through the major mechanisms determining the changes in investment, capital and real GDP.

As a result of China's accession the rental price of capital is 4.3 percent higher than the baseline by 2007. The increase in capital's rental price is the result of increased demand for capital by all industries, but in particular the wearing apparel and auto sectors, where exports increase as a result of the removal of tariffs and quotas (and productivity gains in the case of autos), and the services sectors, where production has increased as a result of the services liberalization and productivity gains. The effect of liberalization in cross border trade in services on the rental price of capital is small $(0.1 \text { percent increase in real GDP })^{20}$ when compared to the potential impact of productivity growth in services, which accounts for 12.2 percent of the 22.5 percent increase in real GDP.

\footnotetext{
${ }^{19}$ This leads to a cumulative change in services productivity of 12.794 , substantially less than the total factor productivity estimated by Mai et al. (2003) which estimated productivity growth of $2.7 \%$ per year. However, Mai et al.'s estimates may be overestimates since they abstract from reform at the border in their study.

${ }^{20}$ This is because cross-border trade in services is a relatively small share of total trade.
} 
In addition, the price of capital goods in China gradually declines over the accession period. ${ }^{21}$ The decline in the price of capital goods is primarily fueled by declines in the prices of domestic intermediates, purchased by the capital goods sector. These prices fall as a result of the removal of tariffs on their imported intermediates and as a result of the productivity gains in the automobile and service sectors. Again, the liberalization of cross border trade in services plays a minor role in the decline in the price of capital goods.

The combined effect of the rise in the rental price of capital and the decline in the price of capital goods causes the rate of return on investment in China to increase. ${ }^{22}$ Figure 4 illustrates the effect of the various features of China's accession on the rate of return. The removal of tariffs and the productivity shocks appear to have the largest impact on the rates of return in China, while the effect of liberalization of cross border trade in services is minimal, due to its limited effect on the price of capital goods and the rental price.

Investment and hence capital stocks increase in response to the higher rates of return in China as a result of WTO accession. These larger capital stocks serve to gradually bring the rate of return down and closer to the global rate of return after 2007 when accession is complete. Eventually, the rate of return in China falls below that in the baseline scenario. This is the result of the capital accumulation mechanisms in the model, which allocate investment in such a way as to eliminate differences in the rates of return across regions.

As a result of WTO accession, 2020 capital stocks increase by 25.8 percent and real GDP by 22.5 percent, relative to the baseline (Table 3). Figure 5 divides the effect on real GDP according to the five components of China's accession. Those components, which lead to increases in the rates of return on capital, have the greatest impact on real GDP.

As mentioned previously, it was assumed that any tax revenue lost as a result of lower tariffs would be replaced with consumption taxes. The power of these taxes rises by 1.32 percent in 2007. As the productivity gains in autos and services take hold, this revenue replacement requirement disappears.

\footnotetext{
${ }^{21}$ This decline would have been much larger if we had not incorporated the pre-existing duty drawbacks on imported intermediate imports purchased for the production of capital goods.

${ }^{22}$ The rate of return is the ratio of these two prices. It ignores capital gains (losses) as GTAP-Dyn is a recursive dynamic model (Ianchovichina and McDougall, 2001).
} 


\section{Domestic and Foreign Ownership}

In this paper we are particularly interested in the impact of WTO accession on domestic and foreign ownership of those capital stocks. Figure 6 shows that the share of foreign ownership in China grew strongly between 1995 and 2002. After 2002, however, growth in foreign ownership in the baseline occurs at a more modest rate (Figure 7). As a consequence, the share of foreign investment in the baseline falls between 2002 and 2020. This decline in the share is due to the fact that China's income and hence savings are growing faster than other regions, hence Chinese households can fund more of China's investment.

With rates of return increasing as a result of China's accession, foreign investment is attracted to China (Figure 7), the share of foreign ownership in Chinese assets also rises (Figure 6) as China's regional investment rises faster than saving. Table 3 reports that foreign wealth located in Chinese assets increases by approximately 126 percent, relative to the baseline by 2020. Most of this increase is due to the boost that China's accession to the WTO is expected to give to productivity (associated with the rise in foreign commercial presence in the service sectors), followed by the reduction in risk premiums, ${ }^{23}$ and tariff liberalization (Figure 7). Foreign (and domestic) ownership are little affected by the liberalization of cross border trade in services.

Each of the elements of WTO accession raises the share of foreign ownership relative to the baseline (Figure 6), however it is only when restrictions on the foreign commercial presence in services are eliminated that the share rises in absolute terms. Eventually however, income and hence saving in China rise sufficiently to cause the domestic share of this investment to rise and the foreign share to fall (2010).

China's accession also increases the total wealth of Chinese households. Figure 8 shows the share of this wealth allocated to foreign assets. In the baseline Chinese households increase their holdings of foreign assets. However with China's accession, higher relative rates of return at home make domestic investments more attractive and the share of Chinese wealth located in foreign assets falls, as the share in domestic firms rises.

\footnotetext{
${ }^{23}$ In Figure 7 the line labeled 'risk' shows the effect on foreign ownership if we assume that the current rising trend in foreign ownership continues. In this case the marked slowdown in growth of foreign ownership in the baseline is reduced. The decline in the share of foreign ownership still occurs, although the effect is delayed (Figure 6).
} 
The increase in capital flows into China is mirrored in the country's trade balance relative GDP -- as reported in Figure 9. The increase in capital flows ${ }^{24}$ causes the trade balance to initially decline. By 2020 when foreign capital flows level off, the increase in income payments to foreign owners of capital causes the trade balance to improve. In the other regions, by 2020, the trade balance declines as imports rise faster than exports in the developed economies, or in the case of the developing economies, as exports decline (Table 3).

It is important to reiterate that domestic and foreign shares of China's investment are held constant, subject to adding up constraints, and hence are only affected by the relative ability of domestic and foreign households to fund investment (i.e. their savings). The model does not take into account other factors which may influence the decisions of foreign and domestic investors, such as differences in their expectations, delays in reforms to China's inefficient state enterprises or financial markets and many of the other problems outlined in the Economist (2000) which may continue to cause foreign investors to be cautious, even after accession. Moreover capital flows relate to investment in physical goods, not the movement of financial capital. Consequently the model does not take account of the possibility that as China opens up its financial markets there will be an outflow of financial capital as Chinese investors seek to diversify their own portfolios. This would increase the extent to which foreign investors could fund new investments in China.

All countries, other than China and Taiwan (China), increase their long run foreign ownership, which is invested primarily in China and to a lesser extent Taiwan (China) (Table 3). By 2020 China reduces its foreign investments abroad, relative to the baseline, choosing instead to invest domestically (Table 3). In contrast to China, real GDP, investment and wealth in the South East and South Asian economies are adversely affected by China's accession to the WTO. This is primarily due to increased competition in the wearing apparel and textiles markets as China's quotas are removed. Total household wealth in South East Asia, however, rises due to the large increase in foreign investment. The Newly Industrialized Economies (NIEs), on the other hand, supply the growing Chinese sectors with intermediate inputs, hence real GDP, capital

\footnotetext{
${ }^{24}$ Financial capital flows, which also affect the capital account, and hence the trade balance, are not included in this model. All foreign capital flows relate to foreign investment in physical capital.
} 
and foreign ownership in the NIEs fall only marginally. The other developed and developing countries also increase their ownership of foreign assets.

Note that if productivity in the services sectors were to increase to a maximum of $2.7 \%$ by 2007 (a cumulative increase in productivity of $12 \%$ over the baseline), as compared to $1 \%$ in the simulation outlined above, foreign investment in China would more than triple as a result of China's accession. Real GDP in China would increase by $35.7 \%$ as compared to the current increase of $22.5 \% .^{25}$

\section{Welfare}

Since GTAP-Dyn does not incorporate an inter-temporal utility function, determining the effect of China's accession on welfare is a difficult task as there is no obvious way of aggregating welfare over time. In addition, the static welfare decomposition that we rely on for purposes of analysis (Huff and Hertel, 2001) is path dependent. ${ }^{26}$ For these reasons, we have opted for a relatively simple, straightforward approach to welfare analysis in which a single comparative static simulation ${ }^{27}$ is performed in the year 2020 to determine the difference in static welfare - at that point in time -- with and without China's accession.

The final column of Table 3 reports the percentage change in the representative regional household's static utility in 2020 owing to China's WTO accession. This change is largest for China (16\%), followed by Taiwan (China) with a 3.1\% increase in 2020 welfare. Other changes are less than $1 \%$. With the exception of South and South East Asia, all regions gain from China's WTO accession.

The first column in Table 4 reports the Equivalent Variation (EV) associated with the changes in regional household utility, and the remainder of that table uses the Huff/Hertel decomposition technique to explain the sources of welfare changes in each region. In the case of China, we see that US\$57 billion of the gain in 2020 is due to improved allocative efficiency lower tariffs improve the allocation of resources between domestic production and imports. The second column of Table 4 shows that China's terms of trade deteriorate as she exports more in

\footnotetext{
${ }^{25}$ The macro results in 2020 for this alternative experiment are provided in Appendix 2.

${ }^{26}$ This means that the welfare results are dependent on the shares in the data base. In a dynamic model the data base is updated each period, and therefore the shares will depend on the policy shock, and hence the path taken.

${ }^{27}$ Further details about the comparative static simulation are provided in Appendix 2.
} 
order to pay for her increased imports. Also, the abolition of the MFA quotas on textiles and apparel means that the associated exporter rents get dissipated in lower export prices. Because WTO accession stimulates investment in China, the capital stock is higher and this contributes US\$40.4 billion to welfare (Table 4). However, a substantial portion of this new investment is foreign-owned and so the associated income payments go overseas. This flow translates into an offsetting US $\$ 13$ billion deduction from China's welfare in the foreign ownership column of Table 4. The other major contributor to welfare in 2020 is the improved productivity. This accounts for a US\$31 billion increment to static, 2020 welfare.

The OECD countries tend to experience a decline in allocative efficiency (Table 4). This is a result of the change in production of taxed or subsidized sectors, including: automobiles (Japan), trade and transport (USA) and/or agriculture $\left(\mathrm{EU}^{28}\right)$ sectors resulting from the production changes in China. The impact in other regions is mixed. Most striking is the US\$2 billion decline in 2020 static efficiency in South Asia, where the volume of trade falls under China's accession. Apart from China and South Asia, the terms of trade improve for all other regions. ${ }^{29}$ The capital and foreign ownership columns are largely offsetting in the non-China regions, since the lower domestic capital stock is offset by increased earnings on foreign investments.

Thus far, we have discussed the economic mechanisms behind the welfare impacts. But which elements of the accession package contribute most to these welfare gains? In Table 5, the welfare (EV) results are decomposed according to the impact on welfare of each element of the accession package. ${ }^{30}$ Overall, the changes in China's welfare are primarily (85\%) due to the productivity improvements in the automobiles and services sectors. The reduction in tariffs by China and the expansion of US and EU quotas on textiles and wearing apparel account for 13 percent of the total welfare gains or \$US13.8 billion. ${ }^{31}$ Hence $52 \%$ of the gains to China are from

\footnotetext{
${ }^{28}$ The fall in allocative efficiency in the EU, resulting from productivity gains in China's automobile sector, is driven by an increase in agricultural production, which is heavily subsidized. Production of automobiles falls, as expected, however the rise in imports of automobiles, which are subject to high tariff rates, causes welfare to rise. ${ }^{29}$ The increase is particularly strong for North America and Europe, where the demand for exports rises and the elimination of textile and apparel quotas on imports results in lower prices for those products.

${ }^{30}$ A complete decomposition of the welfare changes resulting from each of the five elements of accession is provided in Appendix 2.

${ }^{31}$ This finding is consistent with other studies that take into account the duty drawbacks currently in place in China (Ianchovichina et al., 2001).
} 
the productivity gains in services, an effect which is missed by most of the studies on China accession in the literature. ${ }^{32}$

On the other hand, $52 \%$ of the gains to the developed countries are the result of the elimination of tariffs and quotas, as compared to only $13 \%$ for China. However, the improvements in productivity in China still account for a substantial proportion (almost 40\%) of the welfare gains of the other regions. Hence for both China and the other regions these productivity gains are an important aspect of China's accession agreement.

\section{Conclusion}

Foreign investment was a focal point in China's negotiations for accession to the WTO. China has aggressively pursued foreign investment over the past decade - albeit with significant limitations on foreign entry in certain sectors - particularly services. Accordingly, increasing access for foreign investors in the services sectors has been of paramount importance to the US and European negotiators in their dealings with China. In addition, WTO accession will lead to a reduction in tariffs, elimination of quotas on exports of textiles and apparel, and reduction in the barriers to cross-border supply of services. This paper focuses on these elements of China's WTO accession, comparing two alternative time paths of investment and ownership in the Chinese economy over the coming two decades: a no-accession baseline (counterfactual) scenario, and projections under WTO accession.

We used a modified version of the dynamic global applied general equilibrium model, GTAP-Dyn, which explicitly models capital accumulation and foreign ownership as well as taking account of China's existing duty exemption system. Our results show that China's accession to the WTO would boost the Chinese economy and raise rates of return. The resulting increase in capital stocks would be financed by increased domestic investment and foreign investment from industrialized and newly industrialize economies in East Asia, North America and Europe.

\footnotetext{
${ }^{32}$ China's accession may also result in productivity gains in other manufacturing sectors. In textiles and footwear, Claro (2001) states that the adoption rates for foreign technology are between 30 and $62 \%$ for collective enterprises. Mai et al. (2003) also estimate significant productivity gains in the manufacturing sector. These are not captured here.
} 
Central to the increase in China's capital stock are the anticipated productivity gains in the automobile and service sectors. In the automobile sector, this improvement is expected to be fueled by a rationalization of production, as the number of production facilities falls, but the length of run for any given facility increases (Francois and Spinanger, 2002). In the case of services, the productivity gains are expected to come from the opening of the Chinese market to foreign investment. In particular, telecommunications, banking, insurance, logistics and transportation are expected to experience substantial productivity gains as foreign investors induce changes in the organization and operation of these activities. Rather than model the elimination of these barriers to commercial presence directly, we adopt a "dual" approach, whereby we postulate an associated gain in productivity as part of our accession scenario, thereby observing how much foreign investment such gains are likely to sustain. While this part of our analysis is clearly speculative, these productivity shocks are well within the plausible range identified by Mai et al (2003). Since the services component of the accession package is a critical factor in determining the overall impact on GDP and welfare - both in China and in her trade and investment partner economies, further research on the likely productivity gains following accession needs to be undertaken.

The overall size of the potential gains to China is quite substantial. We estimate that GDP could be nearly $22.5 \%$ higher in 2020 as a result of WTO accession. The static welfare gains are lower (16\% in 2020) due to the fact that a substantial share of the additional investment comes from overseas. Nevertheless, these impacts are quite large, and far larger than those predicted by earlier studies which have ignored the impact of accession on productivity in the services sector of China, as well abstracting from capital accumulation and foreign investment. Future research should be directed towards narrowing the uncertainty associated with the impact of accession on productivity in services. 


\section{References}

Anderson, K., J. Francois, T. W. Hertel, B., Hoekman, and W. Martin, (2000): Potential Gains from Trade Reform in the New Millennium, Paper presented at the Third Annual Conference on Global Economic Analysis, June 27-30, Monash University, Australia.

Ahuja, V. and D. Filmer, (1995): "Educational Attainment in Developing Countries; New Estimates and projections Disaggregated by Gender,” World Bank Policy Research Working Paper, 1489, Washington, DC, July.

Baldwin, R.E., J.F. Francois, and R. Portes, (1997):. “The Costs and Benefits of Eastern Enlargement: The Impact on the EU and Central Europe", Economic Policy, April, 127-176.

China Council (2000): China Business Guide, China Council for the Promotion of International Trade / China Chamber of International Commerce (eds), Beijing, China.

China's statistical yearbook (2002): BNP Paribus Peregrine

Claro, S. (2001) 'Tariff and FDI liberalization: What to expect from China's entry into WTO?' paper presented at the eighth annual conference on empirical investigations in international trade, Purdue University, November 911,2001 .

CPB (1999): WorldScan: the Core Version, CPB Netherlands Bureau for Economic Policy Analysis, December.

The Economist (2000): A Survey of China: Now Comes the Hard Part, 8-14 April.

Dixon P. B. and M. T. Rimmer, (2002): Dynamic General Equilibrium Modelling for Forecasting and Policy: a Practical Guide and Documentation of MONASH, North-Holland Publishing Company, Amsterdam.

Francois, J. and Spinanger (2002): Regulated Efficiency, WTO Accession and the Motor Vehicle Sector in China, paper prepared for the conference WTO Accession, Policy Reform and Poverty Reduction, Beijing, June 28-29.

Francois, J. and A. Strutt. (1999): Post Uruguay Round Tariff Vectors for GTAP v.4, Memo, June.

Garbaccio, R. F. (1995): US-China Trade Relations: 1972-95, Paper prepared for the 4th International Symposium on Societies and Economy in East Asia, Oct. 2-3, 1995, Osaka, Japan.

Gilbert, J. and Wahl, T. (2001): "Applied General Equilibrium Assessments of Trade Liberalization in China", World Economy, 25(5): 697-731.

Harrison, G.W., T.F. Rutherford, and D.G. Tarr (1996): “Quantifying the Uruguay Round”, in W. Martin and A. Winters (eds.), The Uruguay Round and the Developing Economies Cambridge: Cambridge University Press, Chapter 7, 183-215.

Hertel, T. W. (ed), (1997): Global Trade Analysis: Modeling and Applications. Cambridge: Cambridge University Press.

Hertel, T. W. and K. Huff, (2001): Decomposing Welfare Changes in GTAP, GTAP Technical Paper No. 5 (revised version), Center for Global Trade Analysis, Purdue University.

Hertel, T. W., W. Martin, K. Yanagishima and B. Dimaranan, (1996): Liberalizing Manufactures Trade in a Changing World Economy@, in W. Martin and A. Winters (eds.), The Uruguay Round and the Developing Economies. Cambridge: Cambridge University Press. Chapter 7, 183-215.

Hertel, T. W., T. L. Walmsley and K. Itakura (2001): "Dynamic Effects of the "New Age" Free Trade Agreement between Japan and Singapore”, Journal of Economic Integration, December, 16(4), 446-448.

Huang, Y. (2002): Selling China: Foreign Direct Investment During the Reform Era, Cambridge University Press. Ianchovichina (2003): GTAP-DD: A Model for Analyzing Trade Reforms in the Presence of Duty Drawbacks, GTAP Technical Paper No. 21, Purdue University (www.gtap.org).

Ianchovichina, E. I. and R. A. McDougall (2001): Structure of Dynamic GTAP, GTAP Technical Paper 17, Center for Global Trade Analysis, (www.gtap.org). 
Ianchovichina, E. I. and W. Martin (2001): “Trade Liberalization in China's Accession to WTO”, Journal of Economic Integration 16(4), December 2001; 421-444.

Ianchovichina, E. and W. Martin (2003): "Economic Impacts of China's Accession to the WTO Accession", Policy Research Working Paper, 3053, World Bank (www.worldbank.org).

Ianchovichina, E. and T. L. Walmsley, (2003): "Impact of China's WTO Accession on East Asia”, Policy Research Working Paper, 3109, World Bank (www.worldbank.org).

Lejour, A., (2000): China and the WTO: the impact on China and the world economy, paper presented at the Third Annual Conference on Global Trade Analysis, Melbourne, Australia, June 27-30.

Maddison, A., (1998): Chinese Economic Performance in the Long Run, Development Centre Studies, OECD.

Mai, Y, M. Horridge and F. Perkins, (2003): Estimating the effects of China's Accession to the World Trade Organisation, CoPS General Paper No. G-137, April. Paper presented at the Sixth Annual Conference on Global Trade Analysis, June 12-14, Scheveningen, The Hague, The Netherlands.

Martin, W., B. Dimaranan, T. Hertel, and E. Ianchovichina (2000): Trade Policy, Structural Change and China's Trade Growth, Working Paper No. 64, Stanford Institute for Economic Policy Research, Stanford.

Mattoo, A. (2001): China's Accession to the WTO: The Services Dimension, paper presented at the Workshop on WTO Accession, Policy Reform, and Poverty Reduction, The World Bank, Beijing, China, October.

McDougall, R. A., A. Elbehri, T. P. Troung. (ed.), (1998): Global Trade, Assistance and Protection: The GTAP 4 Data Base. Center for Global Trade Analysis, Purdue University.

McKibbon, W. J., and K. K. Tang, (2000): “Trade and Financial Reform in China: Impacts on the World Economy”, World Economy, 23(8), August 2000.

Pangestu, M. and D. Mrongowius (2001): Facing the Challenge of WTO Accession: Development and Reform of China's Telecommunications Services Sector, paper presented at the Workshop on WTO Accession, Policy Reform, and Poverty Reduction, The World Bank, Beijing, China, October.

Spinanger, D., (1999): “Textiles beyond the MFA Phase-Out”, World Economy, 22(4), 455-76, June.

Walmsley, T. L., Dimaranan B. V. and R. A. McDougall (2000): A Baseline Scenario for the Dynamic GTAP Model, Center for Global Trade Analysis, Purdue University.

Walmsley, T. L. and T. W. Hertel (2001): "China's Accession to the WTO: Timing is Everything", World Economy 24(8), 1019-49, August.

Wang, Z. (1997a): "China and Taiwan, China access to the World Trade Organization: implications for U.S. agriculture and trade", Agricultural Economics, 17, 239-264.

Wang, Z. (1997b): Impact of China's WTO Accession on the Labor Intensive exports and Implications for U.S. Agricultural Trade -- A Recursive Dynamic CGE Analysis, Paper presented at the1997 AAEA Meeting, July 28-31, Toronto, Canada.

Wang, Z. (2001): The impact of China's WTO Accession on Patterns of World Trade, Paper prepared for the International Agricultural Trade Research Consortium, May 18-20.

Wang, Z. (2002) WTO Accession, "Greater China" Free Trade Area and Economic Relations across the Taiwan Strait, paper presented at the Fifth Conference on Global Economic Analysis, Taipei, June 5-7.

Wenping, L., and C. Findlay (2001): Logistics in China: Accession to the WTO and Its Implications, paper presented at the Workshop on WTO Accession, Policy Reform, and Poverty Reduction, The World Bank, Beijing, China, October.

Yang, Y., (1996): “China’s WTO Membership: What's at Stake?”, The World Economy, 19(6), 661-682. 


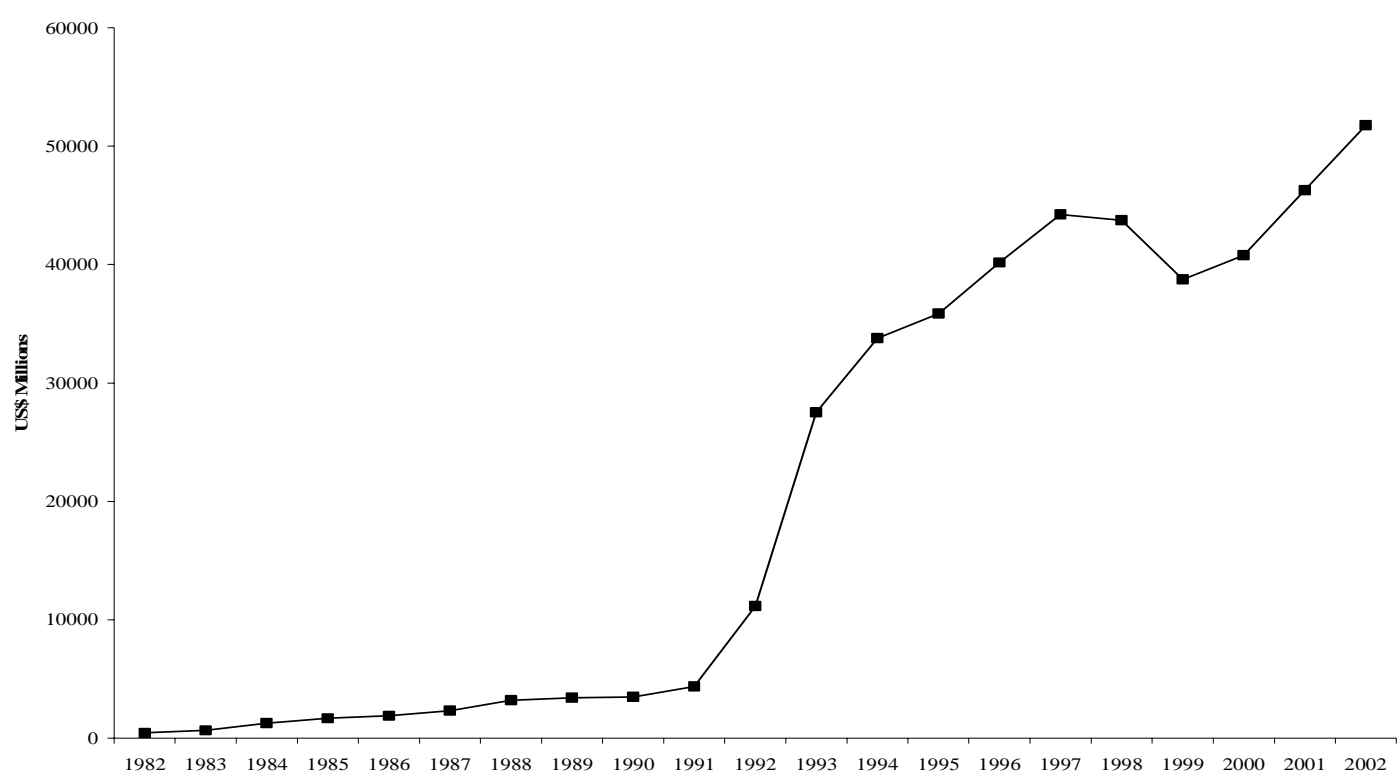

Sources: IMF Balance of Payments Statistics, 1999 and China's statistical yearbook, BNP Paribus Peregrine (US\$ millions).

\section{Figure 2: Expected and Actual Rate of Return Schedules}

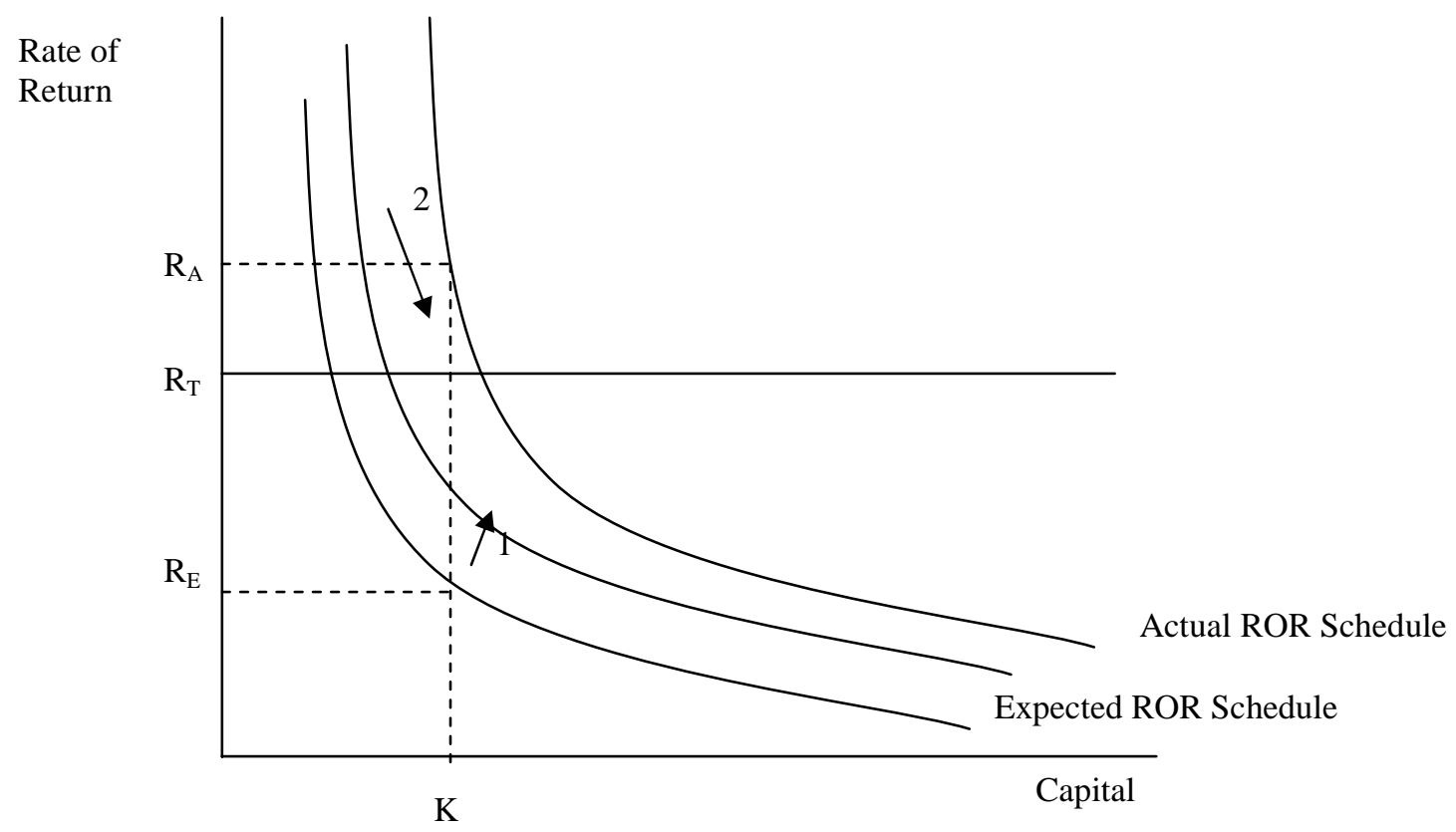

Source: Ianchovichina and McDougall (2001) 


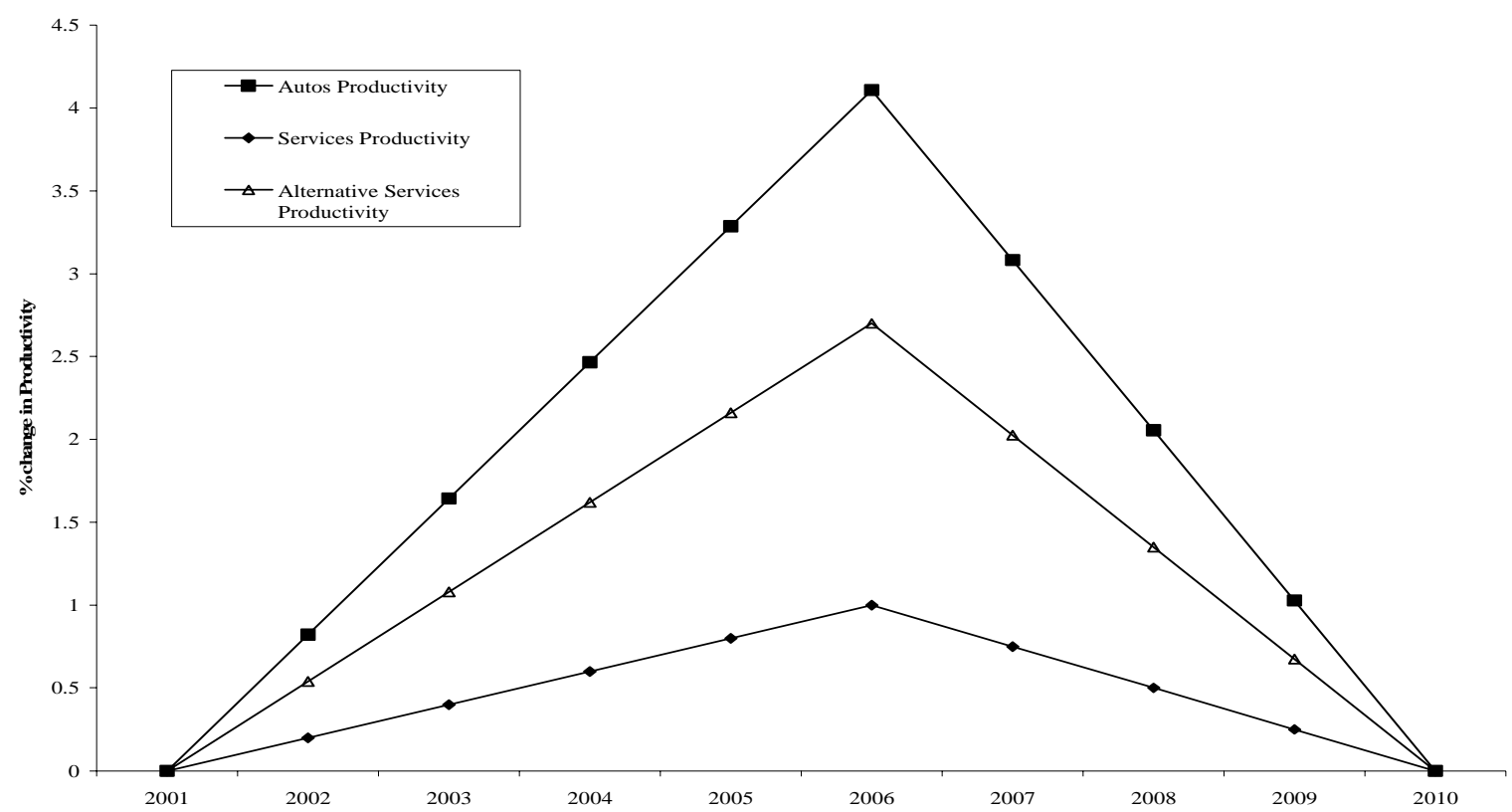

a. 'Alternative services productivity' refers to the case where service sector productivity peaks at $2.7 \%$ (this correspond to the annual productivity gain estimated by Mai et al., 2003). The results of this scenario are examined in Appendix 1.

\section{Figure 4: Cumulative Percentage Differences from Baseline in China's Actual Rate of Return $^{\mathrm{a}}$}

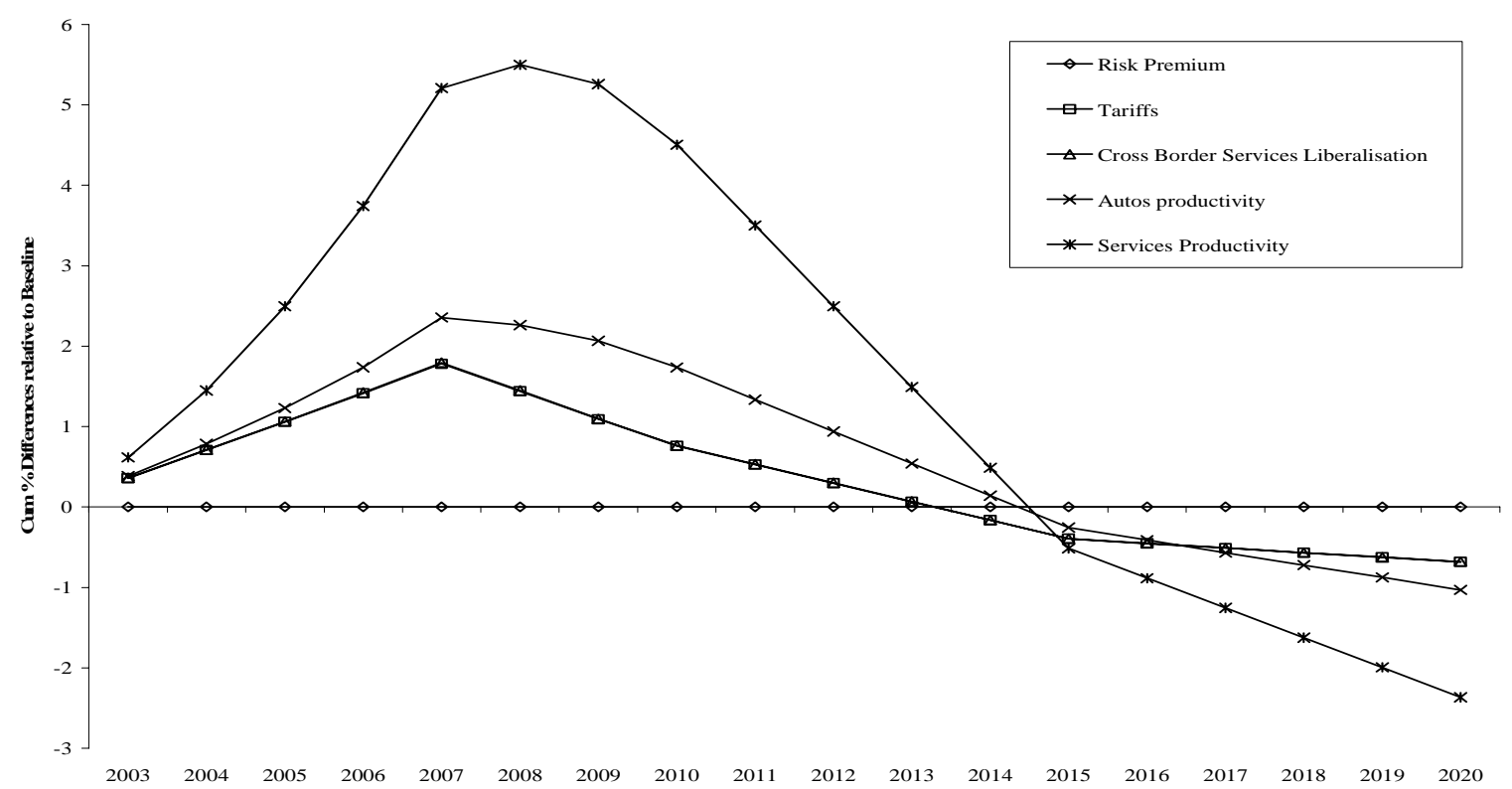

a. Each curve shows the cumulative \% difference between the baseline and the policy. The policy is assumed to be the particular aspect referred to plus all previous shocks listed.

Source: Authors' simulations with GTAP-Dyn. 


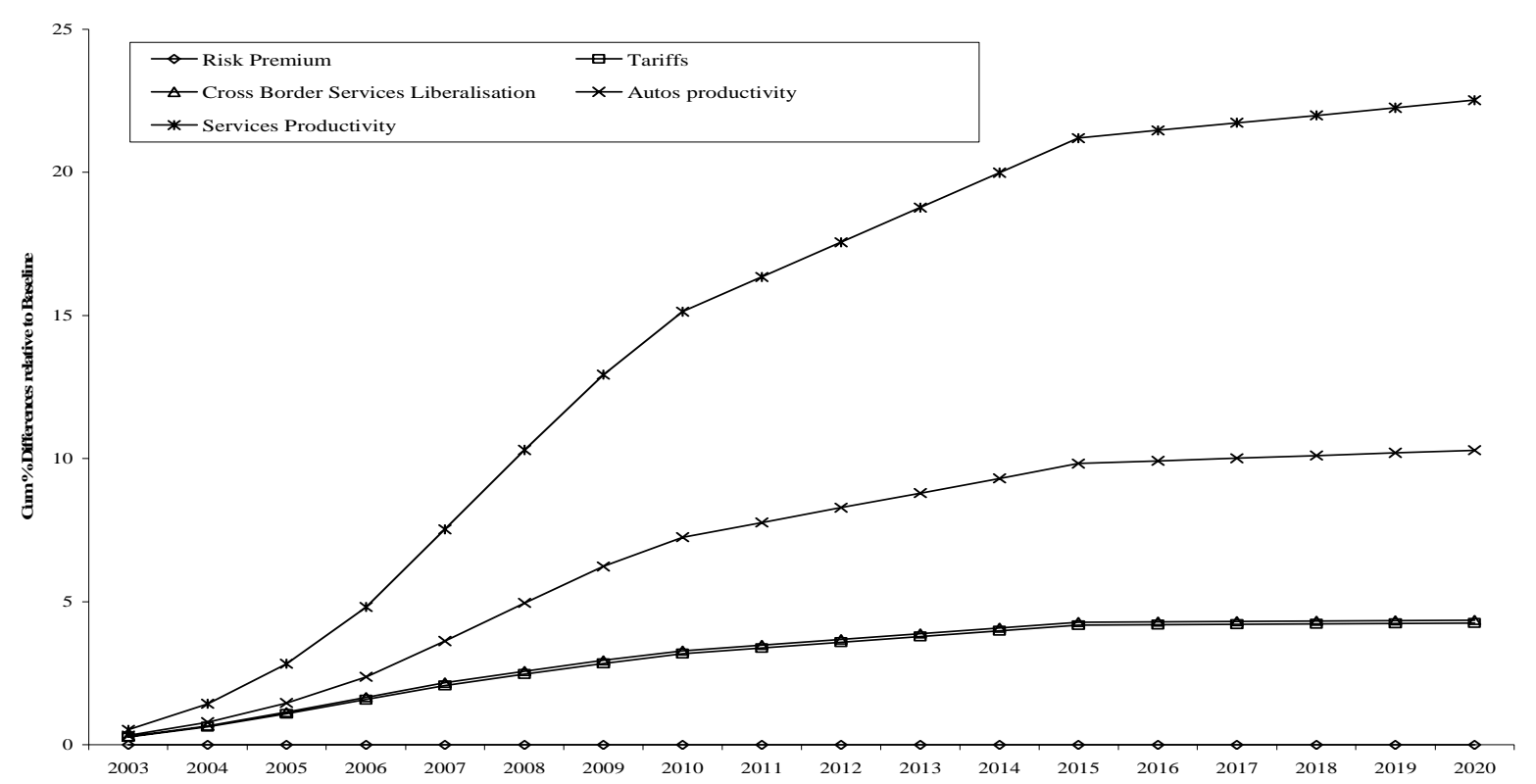

a. Each curve shows the cumulative \% difference between the baseline and the policy. The policy is assumed to be the particular aspect referred to plus all previous shocks.

Source: Authors' simulations with GTAP-Dyn.

\section{Figure 6: Share of Foreign Ownership of Chinese Assets ${ }^{\mathrm{a}}$}

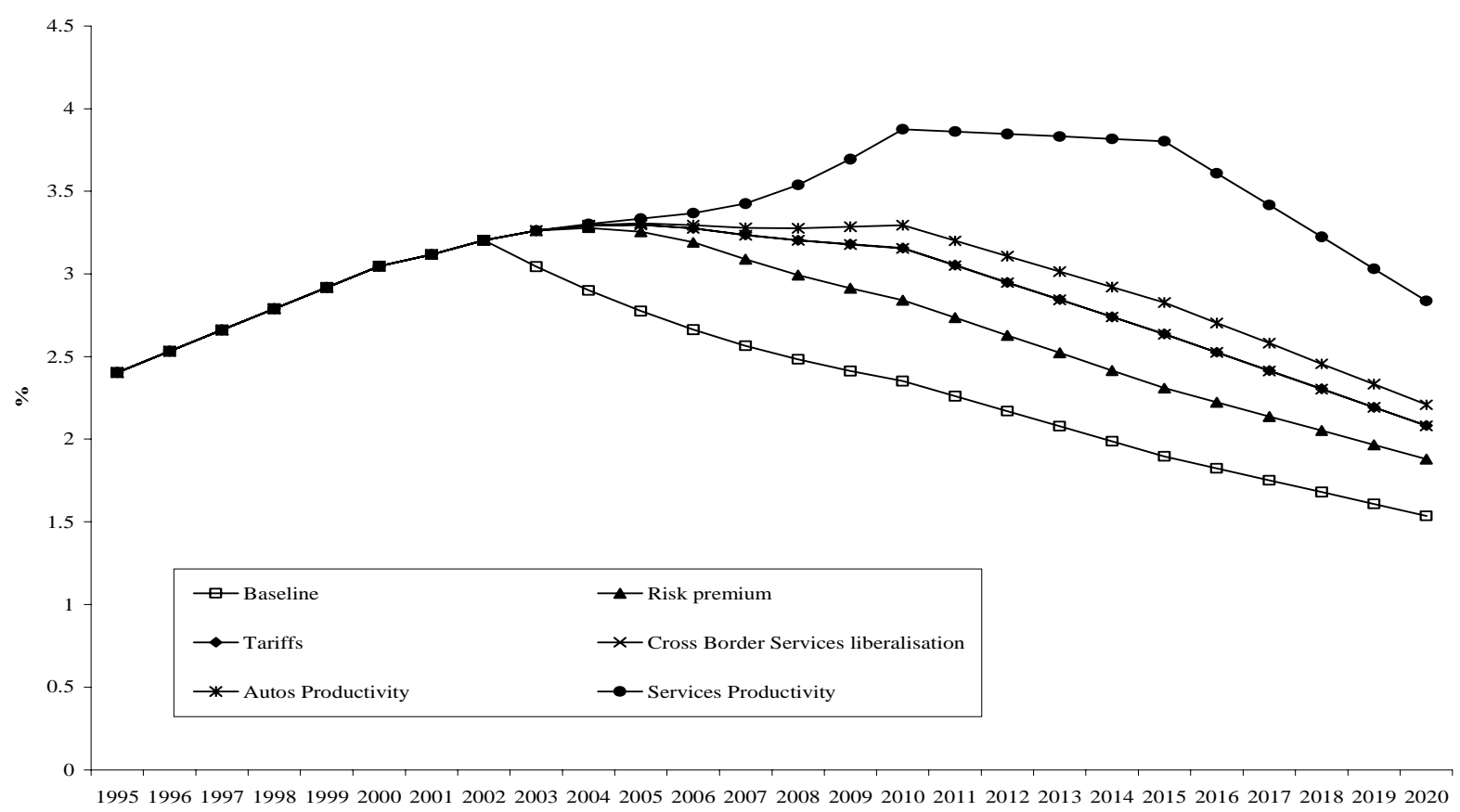

a. Each curve shows the share of foreign ownership of Chinese assets over time resulting from the particular aspect referred to plus all previous shocks.

Source: Authors' simulations with GTAP-Dyn. 


\section{Figure 7: Gross Foreign Ownership of Chinese Assets ${ }^{\mathrm{a}}$}

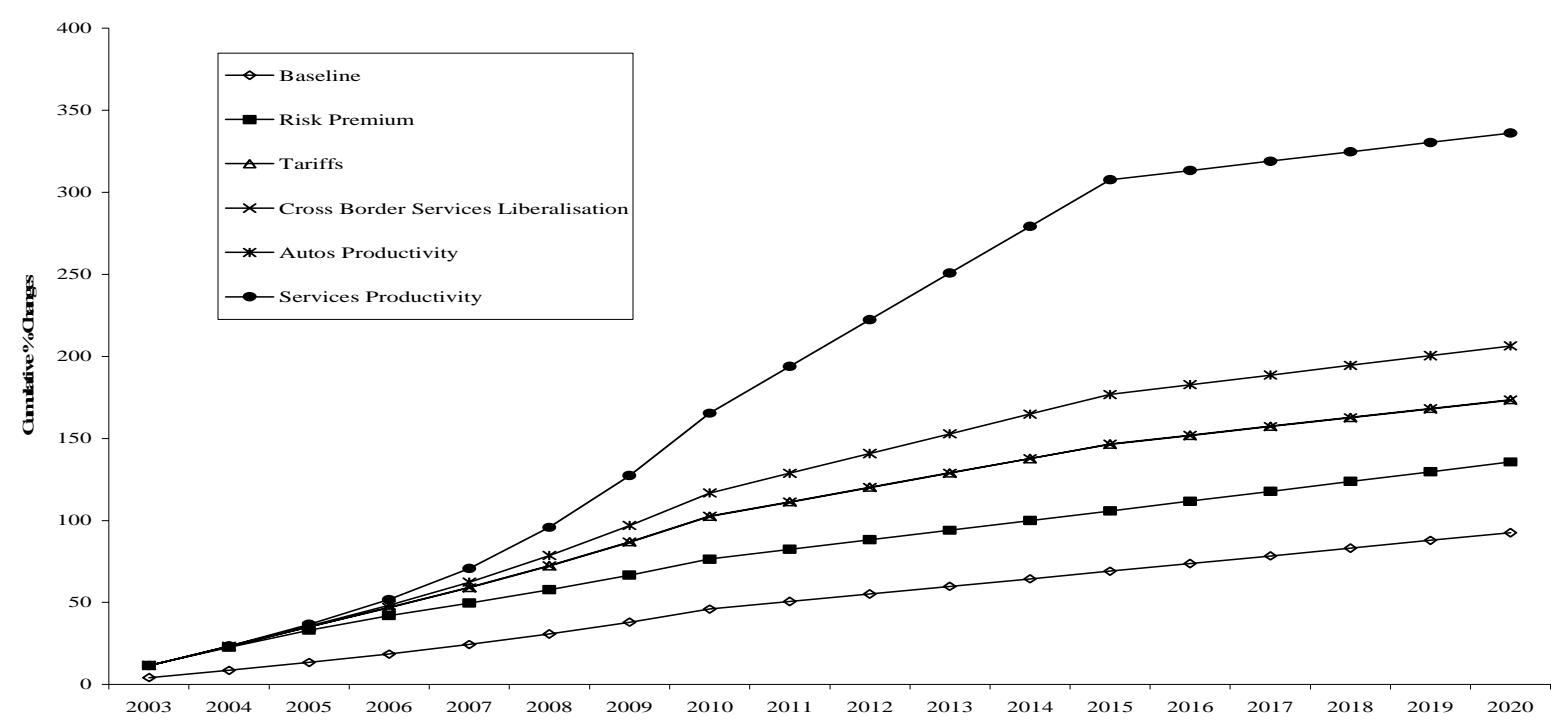

a. Each curve shows the cumulative \% change of foreign ownership of Chinese assets, in the baseline and under each of the policy experiments undertaken.

Source: Authors' simulations with GTAP-Dyn.

\section{Figure 8: Share of Chinese Wealth located in Foreign Assets ${ }^{\mathrm{a}}$}

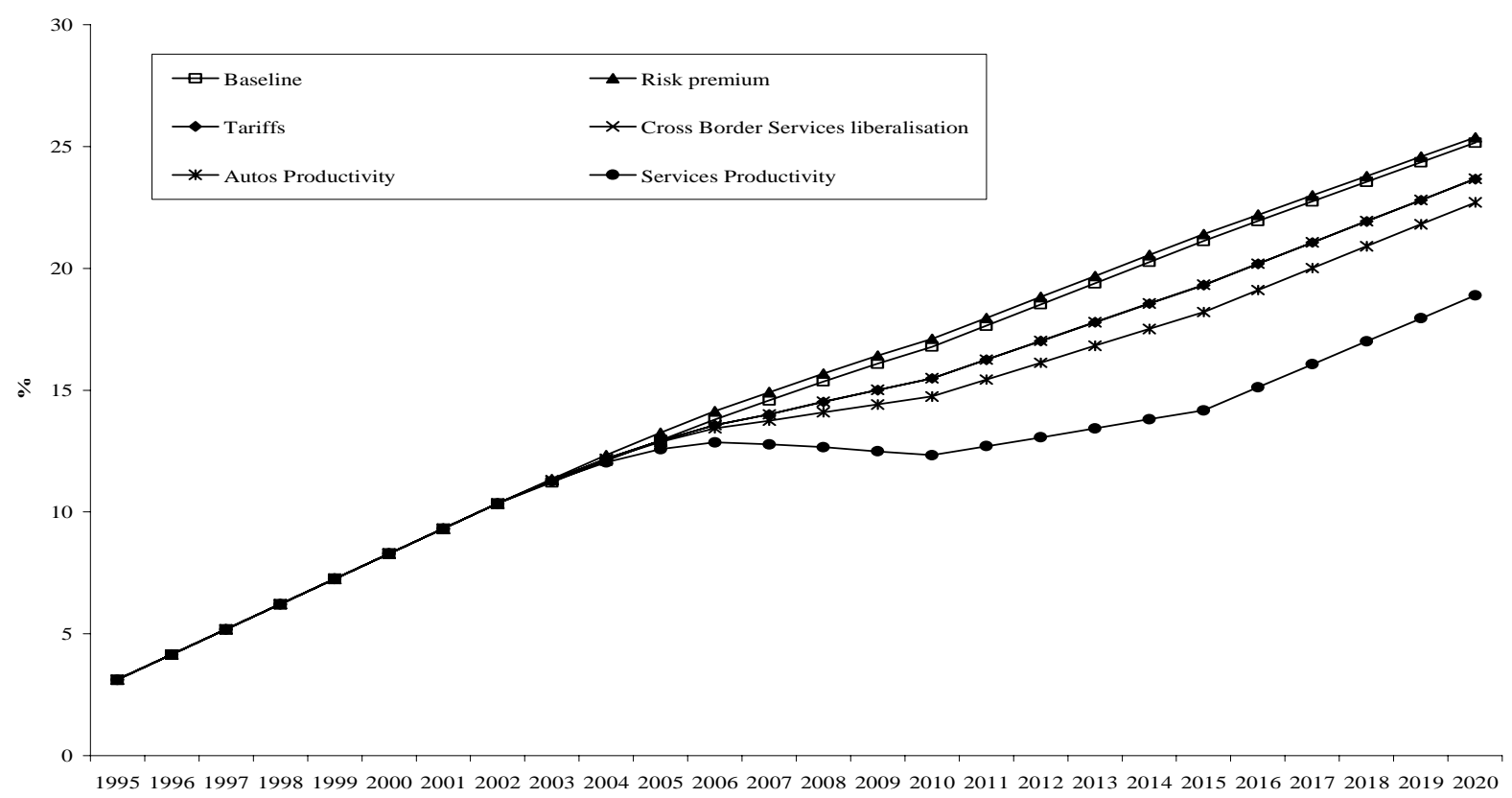

a. Each curve shows the share of Chinese assets located abroad over time resulting from the particular aspect referred to plus all previous shocks. 
Figure 9: Cumulative Difference from Baseline of the Change in China's Trade Balance relative to GDP

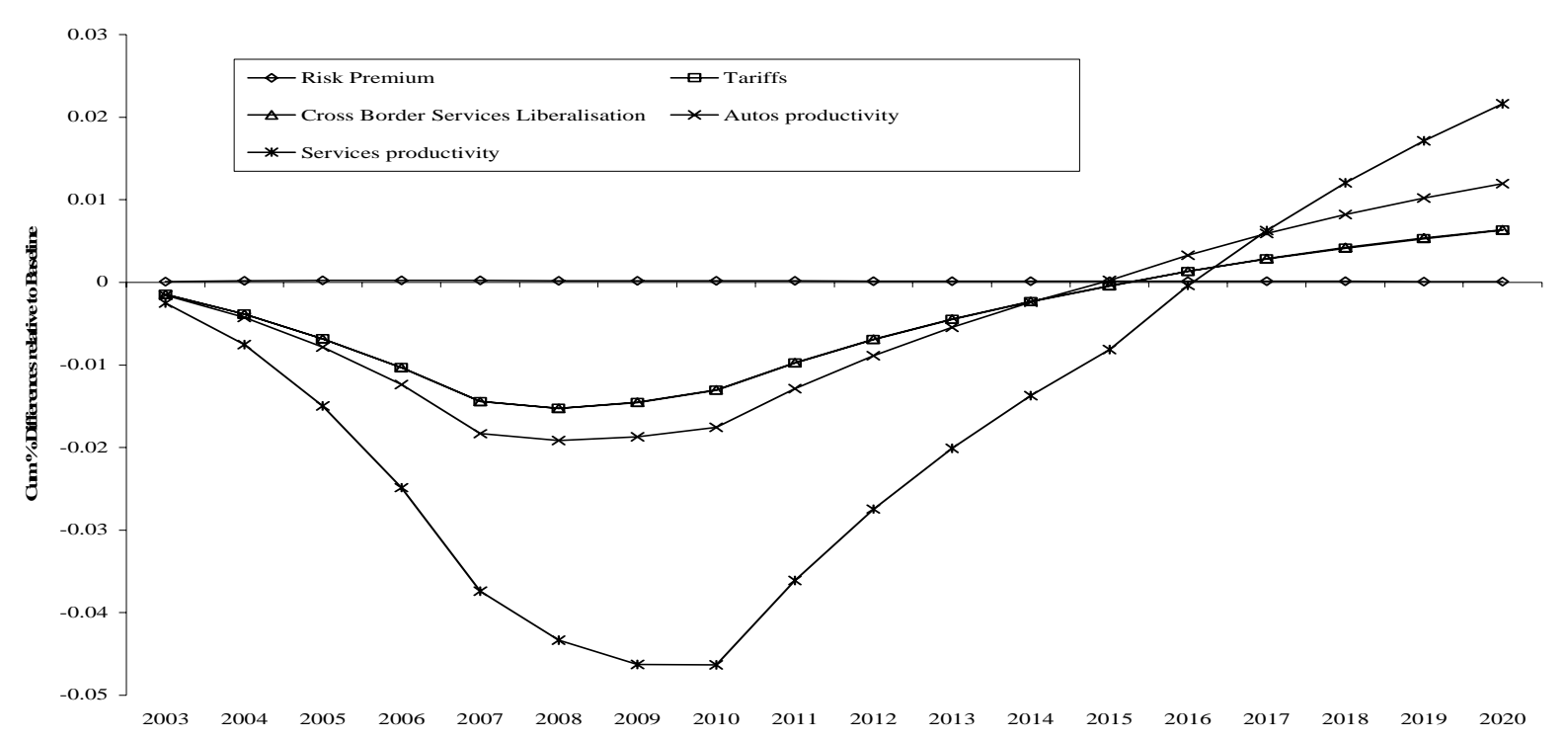

a. Each curve shows the change in the trade balance relative to GDP between the baseline and the policy. The policy is assumed to be the particular aspect referred to plus all previous shocks.

Source: Authors' simulations with GTAP-Dyn.

Table 1: List of Countries and Commodities of the Study

\begin{tabular}{c|c}
\hline Regions & Sectors/Commodities \\
\hline China & Crops \\
Taiwan (China) & Livestock \\
North America & Processed food and Beverages and Tobacco \\
Western Europe & Mining, fish, forestry, petroleum, \\
Japan & Textiles \\
Newly Industrializing & Wearing apparel \\
Countries & Metals and Chemicals \\
South East Asia & Automobiles and parts \\
South Asia & Electronics \\
Latin America & Other Manufactures \\
Africa and Middle East & Household Utilities \\
Rest of World & Trade and Transport \\
& Other Services \\
\hline
\end{tabular}


Table 2: Tariff Barriers, Services Liberalization and Productivity Gains for China ${ }^{a}$

\begin{tabular}{|c|c|c|c|c|c|}
\hline Sectors & 1995 tariffs $^{b}$ & $\begin{array}{c}\text { Tariffs prior } \\
\text { to } \\
\text { Accession }^{\mathrm{c}} \\
\end{array}$ & $\begin{array}{l}\text { Tariffs post } \\
\text { Accession }^{\mathrm{d}}\end{array}$ & $\begin{array}{c}\text { Cross-border } \\
\text { Services } \\
\text { Liberalization }^{\mathrm{e}} \\
\end{array}$ & Productivity $^{\mathrm{f}}$ \\
\hline Crops & 3.92 & -0.39 & -0.39 & & \\
\hline Livestock & 7.33 & 2.30 & 2.30 & & \\
\hline Food and Beverages & 21.51 & 20.90 & 20.25 & & \\
\hline Extraction & 8.50 & 5.45 & 3.46 & & \\
\hline Textiles & 57.52 & 30.39 & 9.25 & & \\
\hline Wearing apparel & 76.12 & 31.84 & 15.80 & & \\
\hline $\begin{array}{c}\text { Metals and } \\
\text { Chemical products }\end{array}$ & 19.26 & 14.82 & 10.87 & & \\
\hline Autos & 129.23 & 31.34 & 20.37 & & 20 \\
\hline Electronics & 22.16 & 12.75 & 4.93 & & \\
\hline Other manufactures & 23.48 & 17.37 & 11.06 & & \\
\hline Household utilities & 0.12 & 0.16 & 0.15 & $\begin{array}{c}5.90 \\
\text { (1.15\% p.a.) }\end{array}$ & 4.6 \\
\hline Trade and transport & 0.00 & 0.00 & 0.00 & $\begin{array}{c}0.92 \\
\text { (0.18\% p.a.) }\end{array}$ & 4.6 \\
\hline Other services & 4.20 & 4.20 & 4.20 & $\begin{array}{c}10.48 \\
(2.01 \% \text { p.a. })\end{array}$ & 4.6 \\
\hline
\end{tabular}

a. Table does not include details of shocks to incorporate the change in the risk premium or the removal of MFA quotas.

b. Tariff Rates in GTAP v.4 data base (1995).

c. Tariff Rates after reductions in baseline. This is due to the fact that China has already undertaken considerable trade liberalization prior to its accession

d. Tariff rates after accession, as per WTO accession agreement (as of August 1999).

e. Cumulative Shocks. Yearly shocks in brackets.

f. Cumulative Shocks. Shocks are applied as per Figure 3. 


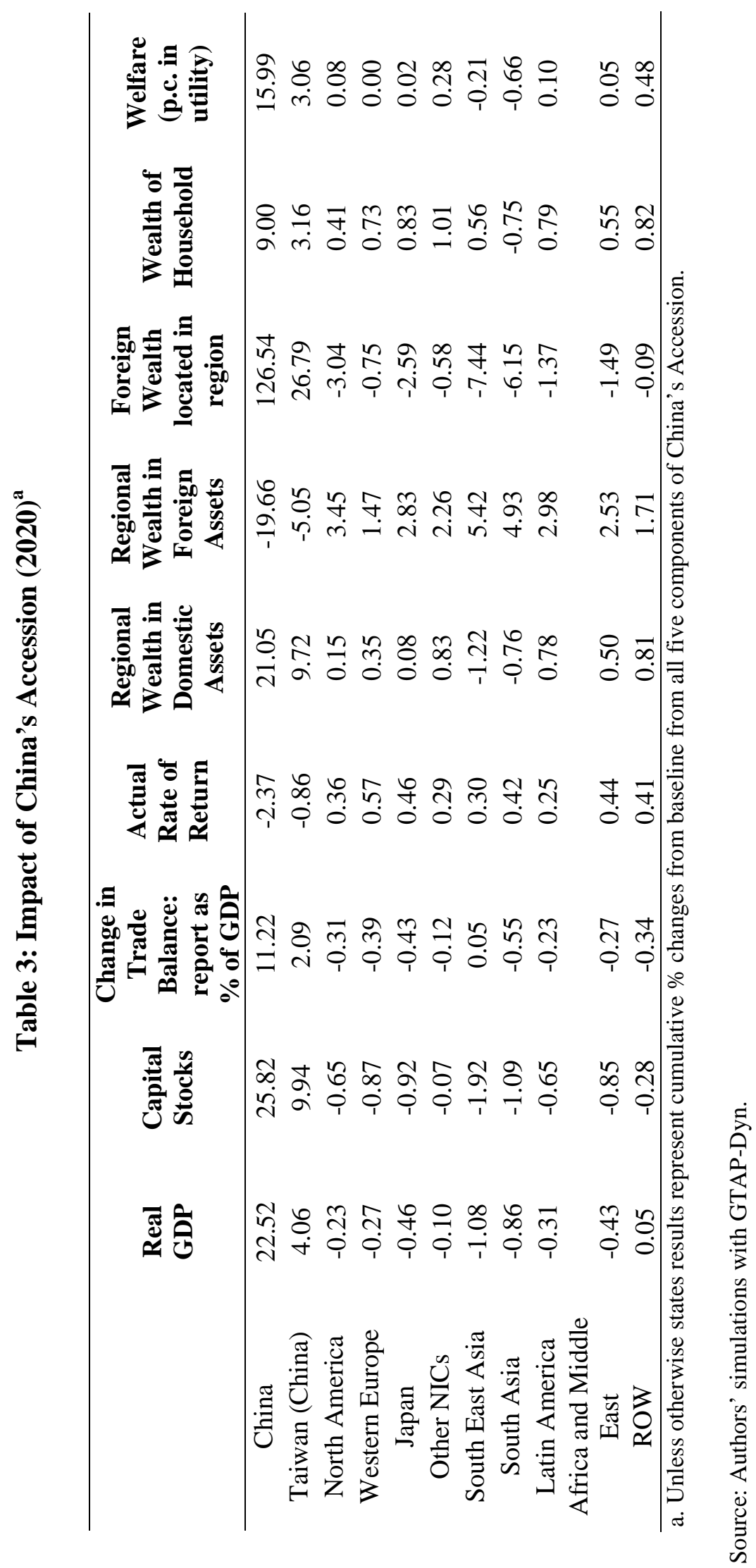


Table 4: Decomposition of Welfare (2020, \$US million)

\begin{tabular}{|c|c|c|c|c|c|c|c|}
\hline & $\begin{array}{c}\text { Total } \\
\text { Welfare }\end{array}$ & $\begin{array}{l}\text { Allocative } \\
\text { Efficiency }\end{array}$ & $\begin{array}{c}\text { Terms of } \\
\text { Trade }\end{array}$ & Capital & $\begin{array}{c}\text { Foreign } \\
\text { Ownership }\end{array}$ & $\begin{array}{c}\text { Tech } \\
\text { change }^{\mathrm{a}}\end{array}$ & Other $^{\mathrm{b}}$ \\
\hline China & 103,433 & 57,625 & $-9,687$ & 40,408 & $-13,255$ & 30,559 & $-2,218$ \\
\hline Taiwan (China) & 7,763 & 1,275 & 2,457 & 5,912 & $-1,886$ & 609 & -604 \\
\hline $\begin{array}{l}\text { North America } \\
\text { Western }\end{array}$ & 5,802 & -454 & 8,787 & $-12,794$ & 10,404 & 0 & -141 \\
\hline Europe & -122 & $-3,970$ & 2,971 & $-9,829$ & 9,432 & 0 & 1,275 \\
\hline Japan & 1,074 & $-5,117$ & 836 & $-9,464$ & 16,743 & 0 & $-1,925$ \\
\hline Other NICs & 1,527 & -204 & 1,318 & -135 & 567 & 0 & -18 \\
\hline $\begin{array}{l}\text { South East } \\
\text { Asia }\end{array}$ & $-1,032$ & -88 & 574 & $-3,729$ & 2,349 & 0 & -139 \\
\hline South Asia & $-2,570$ & $-2,110$ & -554 & -908 & 758 & 0 & 243 \\
\hline Latin America & 1,169 & 281 & 1,780 & $-3,554$ & 1,860 & 0 & 802 \\
\hline $\begin{array}{l}\text { Africa and } \\
\text { Middle East }\end{array}$ & 528 & -730 & 1,888 & $-2,387$ & 1,045 & 0 & 712 \\
\hline ROW & 6,078 & 2,807 & 4,218 & $-1,072$ & -868 & 0 & 992 \\
\hline Total & 123,649 & 49,315 & 14,588 & 2,449 & 27,150 & 31,168 & $-1,022$ \\
\hline
\end{tabular}

a. Due to the productivity shocks in the automobile and services sectors.

b. Other includes changes in welfare due to changes in the price of saving relative to the price of capital goods and due to changes in marginal utility.

Source: Authors' simulations with GTAP-Dyn.

Table 5: Welfare Decomposition by Element of WTO Accession (2020 \$US millions)

\begin{tabular}{lcccccc}
\hline & Total & $\begin{array}{c}\text { Risk } \\
\text { premiums }\end{array}$ & $\begin{array}{c}\text { Tariffs and } \\
\text { Quotas }\end{array}$ & $\begin{array}{c}\text { Services Trade } \\
\text { liberalization }\end{array}$ & $\begin{array}{c}\text { Autos } \\
\text { Productivity }\end{array}$ & $\begin{array}{c}\text { Services } \\
\text { Productivity }\end{array}$ \\
\hline China & 103,433 & -132 & 13,848 & 522 & 34,746 & 54,448 \\
Taiwan (China) & 7,763 & 7 & 6,418 & 521 & 141 & 675 \\
North America & 5,802 & 18 & 5,395 & 246 & $-2,002$ & 2,144 \\
Western Europe & -122 & 137 & 2,464 & 199 & $-2,518$ & -405 \\
Japan & 1,074 & 135 & 1,863 & 66 & $-2,376$ & 1,386 \\
Other NICs & 1,527 & 3 & 797 & 89 & 317 & 321 \\
South East Asia & $-1,032$ & 7 & $-2,320$ & 2 & 2,001 & -722 \\
South Asia & $-2,570$ & 0 & $-1,504$ & 0 & -816 & -250 \\
Latin America & 1,169 & -3 & -188 & 51 & 625 & 685 \\
Africa and Middle East & 528 & -4 & -217 & 67 & 888 & -207 \\
ROW & 6,078 & -4 & 210 & 53 & 3,922 & 1,897 \\
Total & 123,649 & 164 & 26,767 & 1,817 & 34,928 & 59,972 \\
\hline
\end{tabular}

Source: Authors' simulations with GTAP-Dyn. 


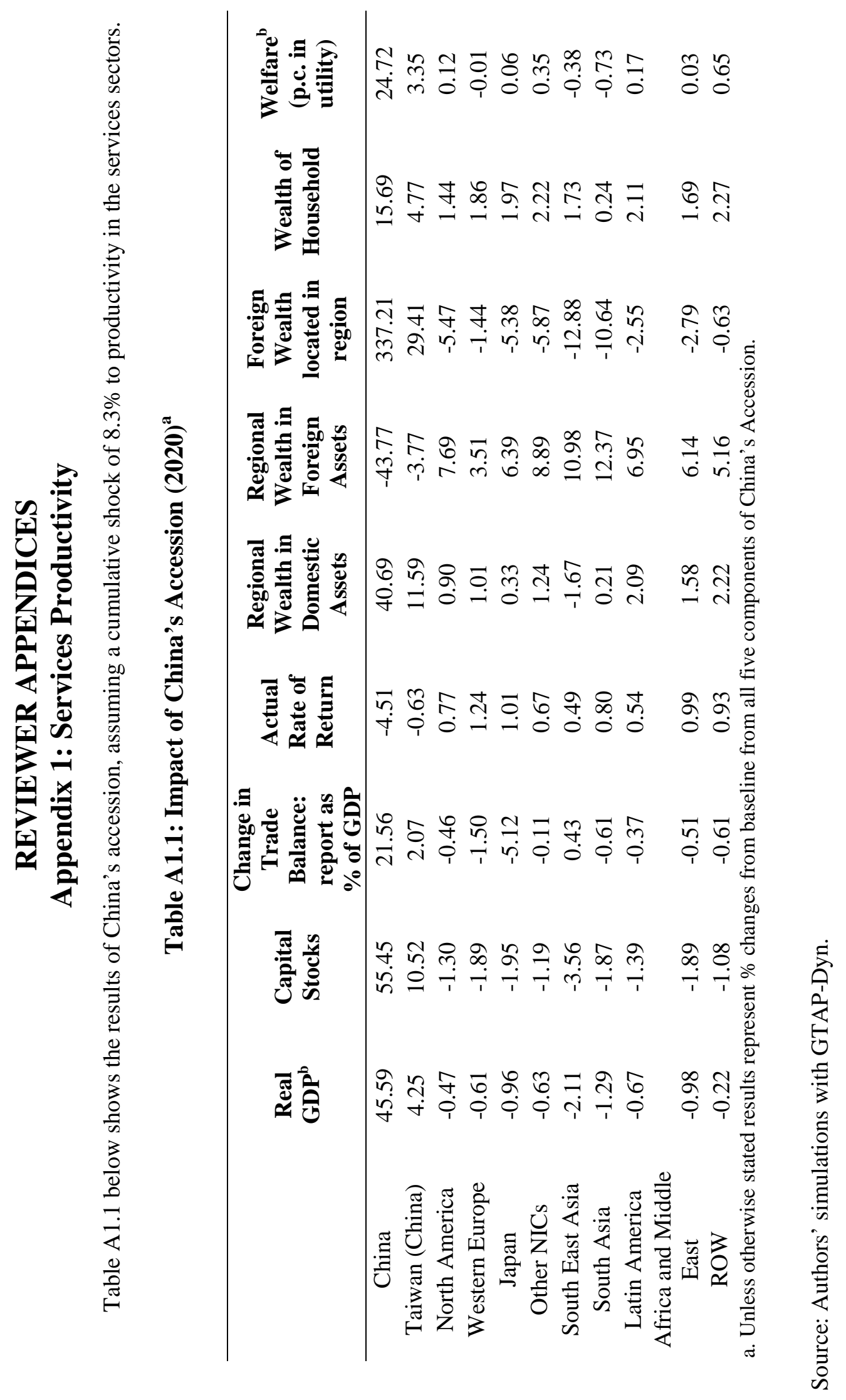




\section{Appendix 2: The Welfare Decomposition}

The comparative static simulation is designed in such a way as to find the difference between the baseline and the policy results in 2020 (i.e. the difference between the base and policy lines is shown in Figure A2.1 as the distance AB). The idea of the comparative static simulation is to start with a common initial data base - the updated baseline data in 2020 - and apply various shocks to the data to obtain the updated policy data base (i.e. move from A to B in Figure A2.1).

The shocks applied to obtain the updated data include the original cumulative policy shocks to risk premium, tariffs and quotas, services liberalization and productivity implemented as part of China's accession to the WTO; shocks to capital stocks and wealth to incorporate the accumulation effects from the GTAP-Dyn into the comparative static simulation and finally to the general price level. These accumulation affects are very important if we wish to include the dynamic effects of China's accession.

All variables, which change endogenously as time passes by (i.e. depend on time in the model), are shocked. These include capital, the normal rate of growth of capital, the expected rate of return, wealth of households and wealth located in the firm. Finally, an adjustment may be required in the general price level to accommodate path dependency in the numeraire. This is due to the fact that in GTAP-Dyn the numeraire is a composite price, which again depends on shares and the path taken. ${ }^{33}$ To remove any path dependency we need to either, change the numeraire to a basic price and shock it by the cumulative percentage change found in GTAP-Dyn simulations or estimate the effect of path dependency on the numeraire and shock the numeraire by this amount. Both of these methods should provide the same result.

The decomposed welfare results for each of the five aspects of China's accession are provided in Table A2.1, Part I to V, below.

\footnotetext{
${ }^{33}$ The standard numeraire in the GTAP-Dyn model is used (psavewld). This is a weighted average of the price of saving in all regions.
} 
Figure A2.1: The Welfare Decomposition

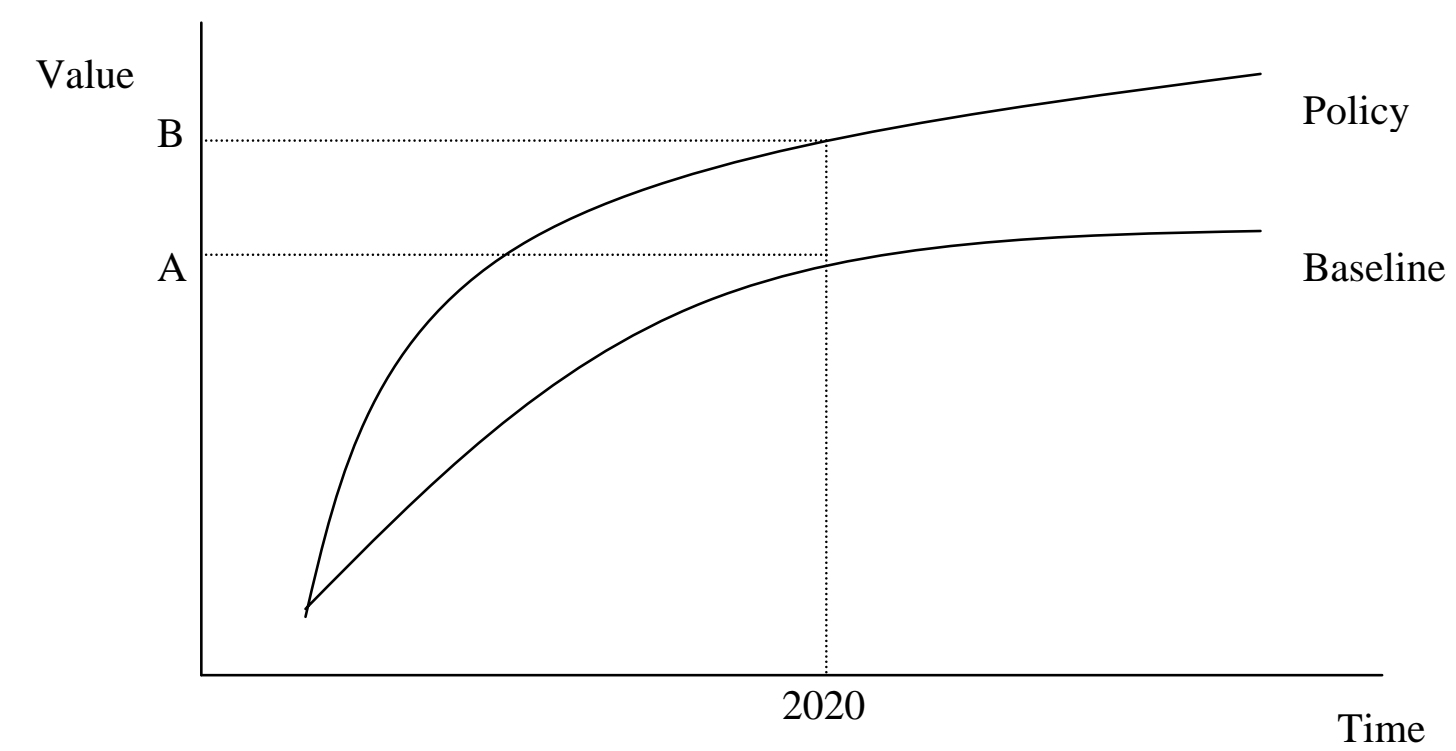

Table A2.1: Decomposition of Welfare by the Five elements of China's Accession (2020, \$US Millions)

\begin{tabular}{c|ccccccc}
\hline \multicolumn{7}{c}{ Part I: Risk } \\
\hline & $\begin{array}{c}\text { Total } \\
\text { Welfare }\end{array}$ & $\begin{array}{c}\text { Allocative } \\
\text { Efficiency }\end{array}$ & $\begin{array}{c}\text { Terms of } \\
\text { Trade }\end{array}$ & Capital & $\begin{array}{c}\text { Foreign } \\
\text { Ownership }\end{array}$ & $\begin{array}{c}\text { Tech } \\
\text { change }\end{array}$ & Other $^{\mathbf{a}}$ \\
\hline China & -131.82 & 1.27 & -6.81 & 2.20 & -132.33 & 0.00 & 3.85 \\
Taiwan (China) & 7.36 & 0.12 & 0.36 & -0.36 & 7.74 & 0.00 & -0.49 \\
North America & 18.04 & 0.57 & 1.88 & -27.70 & 43.78 & 0.00 & -0.50 \\
Western Europe & 136.96 & 17.75 & 7.31 & -23.24 & 145.08 & 0.00 & -9.94 \\
Japan & 134.51 & -0.18 & 8.88 & -17.81 & 148.40 & 0.00 & -4.77 \\
Other NICs & 3.06 & -0.90 & 0.50 & -4.93 & 8.70 & 0.00 & -0.30 \\
South East Asia & 7.20 & -0.67 & 0.49 & -2.97 & 10.72 & 0.00 & -0.36 \\
South Asia & -0.39 & -0.37 & 0.23 & -0.98 & 0.73 & 0.00 & 0.00 \\
Latin America & -3.37 & -1.03 & 0.01 & -9.34 & 6.79 & 0.00 & 0.19 \\
Africa and & & & & & & & \\
Middle East & -3.60 & -2.62 & 0.71 & -6.68 & 4.82 & 0.00 & 0.18 \\
ROW & -3.66 & -0.61 & -0.58 & -8.63 & 5.98 & 0.00 & 0.19 \\
Total & 164.31 & 13.33 & 12.97 & -100.45 & 250.41 & 0.00 & -11.95 \\
\hline
\end{tabular}




\begin{tabular}{c|ccccccc}
\hline \multicolumn{7}{c}{ Part II: Tariffs and Quotas } \\
\hline & $\begin{array}{c}\text { Total } \\
\text { Welfare }\end{array}$ & $\begin{array}{c}\text { Allocative } \\
\text { Efficiency }\end{array}$ & $\begin{array}{c}\text { Terms of } \\
\text { Trade }\end{array}$ & Capital & $\begin{array}{c}\text { Foreign } \\
\text { Ownership }\end{array}$ & $\begin{array}{c}\text { Tech } \\
\text { change }\end{array}$ & Other $^{\mathbf{a}}$ \\
\hline China & $13,848.02$ & $12,098.36$ & $-4,032.78$ & $9,459.50$ & $-3,509.84$ & 0.00 & -167.22 \\
Taiwan (China) & $6,418.21$ & $1,549.30$ & $1,793.53$ & $5,412.28$ & $-1,953.83$ & 0.00 & -383.08 \\
North America & $5,395.40$ & $1,581.45$ & $4,955.88$ & $-4,496.26$ & $3,474.43$ & 0.00 & -120.11 \\
Western Europe & $2,463.80$ & 657.74 & $1,950.76$ & $-2,420.80$ & $2,218.03$ & 0.00 & 58.07 \\
Japan & $1,863.35$ & -466.69 & 804.90 & $-2,232.41$ & $4,375.17$ & 0.00 & -617.60 \\
Other NICs & 796.83 & 147.35 & 516.19 & 226.57 & -61.76 & 0.00 & -31.52 \\
South East Asia & $-2,320.27$ & -518.35 & -306.57 & $-2,698.58$ & $1,176.89$ & 0.00 & 26.35 \\
South Asia & $-1,503.75$ & -828.38 & -492.26 & $-1,088.85$ & 808.21 & 0.00 & 97.53 \\
Latin America & -188.47 & -108.51 & 231.95 & $-1,517.70$ & $1,014.25$ & 0.00 & 191.55 \\
Africa and & & & & & & & \\
Middle East & -216.52 & -272.60 & 303.69 & -833.97 & 373.02 & 0.00 & 213.34 \\
ROW & 210.40 & 86.06 & 453.22 & -909.16 & 214.63 & 0.00 & 365.65 \\
Total & $26,766.99$ & $13,925.71$ & $6,178.52$ & $-1,099.38$ & $8,129.20$ & 0.00 & -367.05 \\
\hline
\end{tabular}

\begin{tabular}{c|ccccccc}
\hline \multicolumn{7}{c}{ Part III: Services Liberalization } \\
\hline & $\begin{array}{c}\text { Total } \\
\text { Welfare }\end{array}$ & $\begin{array}{c}\text { Allocative } \\
\text { Efficiency }\end{array}$ & $\begin{array}{c}\text { Terms of } \\
\text { Trade }\end{array}$ & Capital & $\begin{array}{c}\text { Foreign } \\
\text { Ownership }\end{array}$ & $\begin{array}{c}\text { Tech } \\
\text { change }\end{array}$ & Other $^{\mathbf{a}}$ \\
\hline China & 522.38 & 119.75 & -119.00 & 45.01 & 35.00 & 447.71 & -6.09 \\
Taiwan (China) & 521.49 & 44.22 & -142.31 & 124.99 & -75.85 & 605.30 & -34.86 \\
North America & 246.34 & 71.51 & 175.71 & -66.65 & 71.13 & 0.00 & -5.35 \\
Western Europe & 199.27 & 56.42 & 135.98 & 32.00 & -20.18 & 0.00 & -4.96 \\
Japan & 65.66 & -24.91 & 38.03 & -81.22 & 158.21 & 0.00 & -24.45 \\
Other NICs & 89.37 & -4.32 & 72.61 & 60.33 & -33.07 & 0.00 & -6.18 \\
South East Asia & 1.53 & -12.25 & 17.62 & -18.08 & 17.06 & 0.00 & -2.82 \\
South Asia & 0.34 & -11.79 & 11.10 & 12.97 & -12.33 & 0.00 & 0.40 \\
Latin America & 51.50 & 18.58 & 45.40 & 13.69 & -45.67 & 0.00 & 19.50 \\
Africa and & & & & & & & \\
Middle East & 66.71 & 26.81 & 42.40 & 4.66 & -25.07 & 0.00 & 17.91 \\
ROW & 52.78 & 17.44 & 44.93 & -12.20 & -15.15 & 0.00 & 17.77 \\
Total & $1,817.38$ & 301.47 & 322.47 & 115.49 & 54.08 & $1,053.01$ & -29.14 \\
\hline
\end{tabular}




\begin{tabular}{c|ccccccc}
\hline \multicolumn{7}{c}{ Part IV: Autos Productivity } \\
\hline & $\begin{array}{c}\text { Total } \\
\text { Welfare }\end{array}$ & $\begin{array}{c}\text { Allocative } \\
\text { Efficiency }\end{array}$ & $\begin{array}{c}\text { Terms of } \\
\text { Trade }\end{array}$ & Capital & $\begin{array}{c}\text { Foreign } \\
\text { Ownership }\end{array}$ & $\begin{array}{c}\text { Tech } \\
\text { change }\end{array}$ & Other $^{\mathbf{a}}$ \\
\hline China & $34,746.38$ & $26,505.38$ & $-1,067.23$ & $7,175.47$ & -709.77 & $4,119.91$ & $-1,277.38$ \\
Taiwan (China) & 140.97 & -344.36 & 379.54 & 168.60 & -73.81 & 1.72 & 9.29 \\
North America & $-2,002.05$ & $-1,634.38$ & -540.24 & $-1,453.90$ & $1,733.69$ & 0.00 & -107.22 \\
Western Europe & $-2,517.51$ & $-1,512.21$ & $-1,133.35$ & $-1,482.17$ & $1,196.41$ & 0.00 & 413.81 \\
Japan & $-2,375.91$ & $-2,184.18$ & -490.79 & $-1,370.44$ & $1,394.52$ & 0.00 & 274.99 \\
Other NICs & 316.88 & -264.40 & 327.96 & 702.95 & -458.47 & 0.00 & 8.84 \\
South East Asia & $2,001.15$ & 833.30 & 609.95 & 635.55 & -43.97 & 0.00 & -33.67 \\
South Asia & -816.25 & -939.99 & -129.82 & 488.11 & -309.89 & 0.00 & 75.34 \\
Latin America & 624.57 & 229.57 & 326.06 & 5.84 & 141.32 & 0.00 & -78.22 \\
Africa and & & & & & & & \\
Middle East & 888.22 & 88.06 & 819.66 & -70.16 & 338.40 & 0.00 & -287.73 \\
ROW & $3,921.58$ & $2,198.78$ & $1,693.60$ & $1,474.33$ & -956.31 & 0.00 & -488.82 \\
Total & $34,928.03$ & $22,975.57$ & 795.34 & $6,274.18$ & $2,252.10$ & $4,121.63$ & $-1,490.79$ \\
\hline
\end{tabular}

\begin{tabular}{c|ccccccc}
\hline \multicolumn{7}{c}{ Part V: Services Productivity } \\
\hline & $\begin{array}{c}\text { Total } \\
\text { Welfare }\end{array}$ & $\begin{array}{c}\text { Allocative } \\
\text { Efficiency }\end{array}$ & $\begin{array}{c}\text { Terms of } \\
\text { Trade }\end{array}$ & Capital & $\begin{array}{c}\text { Foreign } \\
\text { Ownership }\end{array}$ & $\begin{array}{c}\text { Tech } \\
\text { change }\end{array}$ & Other $^{\mathbf{a}}$ \\
\hline China & $54,447.96$ & $18,900.66$ & $-4,460.70$ & $23,726.21$ & $-8,937.76$ & $25,991.08$ & -771.52 \\
Taiwan (China) & 675.07 & 26.12 & 426.01 & 206.38 & 209.49 & 2.17 & -195.11 \\
North America & $2,143.78$ & -473.57 & $4,193.41$ & $-6,749.43$ & $5,080.82$ & 0.00 & 92.56 \\
Western Europe & -404.82 & $-3,190.17$ & $2,010.23$ & $-5,935.12$ & $5,892.66$ & 0.00 & 817.59 \\
Japan & $1,385.92$ & $-2,440.99$ & 475.13 & $-5,761.98$ & $10,666.72$ & 0.00 & $-1,552.96$ \\
Other NICs & 321.16 & -82.22 & 400.61 & $-1,120.11$ & $1,111.89$ & 0.00 & 10.99 \\
South East Asia & -721.72 & -389.63 & 252.78 & $-1,644.62$ & $1,188.64$ & 0.00 & -128.89 \\
South Asia & -250.20 & -329.54 & 56.95 & -318.82 & 271.31 & 0.00 & 69.89 \\
Latin America & 684.91 & 142.54 & $1,176.55$ & $-2,046.39$ & 743.08 & 0.00 & 669.13 \\
Africa and & & & & & & & \\
Middle East & -206.76 & -569.21 & 721.32 & $-1,480.97$ & 354.11 & 0.00 & 767.98 \\
ROW & $1,896.52$ & 505.12 & $2,026.68$ & $-1,616.03$ & -116.70 & 0.00 & $1,097.45$ \\
Total & $59,971.83$ & $12,099.12$ & $7,278.97$ & $-2,740.90$ & $16,464.27$ & $25,993.25$ & 877.12 \\
\hline
\end{tabular}

a. Other includes changes in welfare due to changes in the price of saving relative to the price of capital goods and to changes in marginal utility. 